\title{
Metasomatic Evolution of Coesite-Bearing Diamondiferous Eclogite from the Udachnaya Kimberlite
}

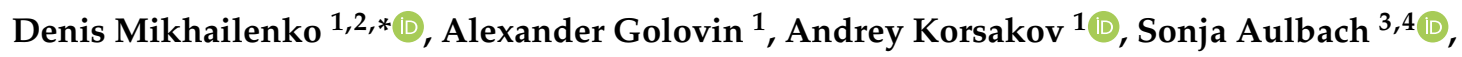 \\ Axel Gerdes ${ }^{3,4}$ (D) and Alexey Ragozin ${ }^{1}(\mathbb{D}$ \\ 1 Sobolev Institute of Geology and Mineralogy, Siberian Branch of the Russian Academy of Sciences, \\ Novosibirsk 630090, Russia; avg@igm.nsc.ru (A.G.); korsakov@igm.nsc.ru (A.K.); ragoz@igm.nsc.ru (A.R.) \\ 2 State Key Laboratory of Isotope Geochemistry, Guangzhou Institute of Geochemistry, \\ Chinese Academy of Science, Guangzhou 510640, China \\ 3 Institut für Geowissenschaften, Goethe-Universität, Frankfurt am Main, 60323 Frankfurt, Germany; \\ s.aulbach@em.uni-frankfurt.de (S.A.); gerdes@em.uni-frankfurt.de (A.G.) \\ 4 Frankfurt Isotope and Element Research Center (FIERCE), Goethe- Universität Frankfurt, \\ Frankfurt am Main, 60323 Frankfurt, Germany \\ * Correspondence: pazilovdenis@igm.nsc.ru
}

Received: 4 December 2019; Accepted: 19 April 2020; Published: 24 April 2020

\begin{abstract}
A coesite-bearing diamondiferous eclogite from the Udachnaya kimberlite (Daldyn field, Siberian craton) has been studied to trace its complex evolution recorded in rock-forming and minor mineral constituents. The eclogite sample is composed of rock-forming omphacite ( $60 \mathrm{vol} \%)$, garnet $(35 \mathrm{vol} \%)$ and quartz/coesite ( $5 \mathrm{vol} \%)$ and contains intergranular euhedral zoned olivine crystals, up to $200 \mu \mathrm{m}$ long, coexisting with phlogopite, orthopyroxene, clinopyroxene (secondary), K-feldspar, plagioclase, spinel, sodalite and djerfisherite. Garnet grains are zoned, with a relatively homogeneous core and a more magnesian overgrowth rim. The rim zones further differ from the core in having higher $\mathrm{Zr} / \mathrm{Y}$ (6 times that in the cores), ascribed to interaction with, or precipitation from, a kimberlite-related melt. Judging by pressure-temperature estimates $\left(\sim 1200{ }^{\circ} \mathrm{C} ; 6.2 \mathrm{GPa}\right)$, the xenolith originated at depths of $\sim 180-200 \mathrm{~km}$ at the base of the continental lithosphere. The spatial coexistence of olivine, orthopyroxene and coesite/quartz with $\mathrm{K}-\mathrm{Na}-\mathrm{Cl}$ minerals in the xenolith indicates that eclogite reacted with a deep-seated kimberlite melt. However, Fe-rich olivine, orthopyroxene and low-pressure minerals (sodalite and djerfisherite) likely result from metasomatic reaction at shallower depths during transport of the eclogite by the erupting kimberlite melt. Our results demonstrate that a mixed eclogitic-peridotitic paragenesis, reported previously from inclusions in diamond, can form by interaction of eclogite and a kimberlite-related melt.
\end{abstract}

Keywords: eclogite; lithospheric mantle; kimberlite; Udachnaya pipe; melting; metasomatism

\section{Introduction}

The origin of eclogite is commonly attributed to the subduction and recycling of Archaean oceanic crust, based on signatures of low-pressure and low-temperature processes (e.g., non-mantle $\mathrm{O}$ isotope ratios, Eu anomalies requiring accumulation or fractionation of plagioclase), sometimes followed by mantle metasomatism during their residence in the cratonic mantle lithosphere [1-3]. Therefore, mantle-derived eclogites (i.e., those that last resided in the continental lithospheric mantle before entrainment in the kimberlite) can furnish unique information on the Precambrian history of oceanic crust and processes in the upper mantle. [4,5]. To date, there are two eclogite formation models-subduction, which became the paradigm, and high-pressure magmatic. Within the subduction 
model, xenoliths of eclogites are the results of the subduction of metamorphosed oceanic crust $[2,6]$, whilst within the magmatic hypothesis, the eclogites are being interpreted as igneous rocks that crystallized at a high pressure. Subducted eclogites have experienced a complex history, as partial melts and as cumulates whose history potentially involved seafloor alteration, subduction, devolatilization, metamorphism, metasomatism and partial melting [2,3]. Moreover, metasomatic processes are expressed as phase changes and modifications of element abundances, element ratios and isotope compositions. The imprints from metasomatism blur the original nature of these rocks.

Eclogitic xenoliths are found in many kimberlites worldwide and bear a record of their metamorphic and metasomatic evolution, from the low-pressure protolith to residence in the mantle lithosphere and finally kimberlite eruption. Indeed, the natural setting of diamonds in their eclogite host rocks, as well as the mineral inclusions in diamonds recovered from such xenoliths provides additional support for the metasomatic origin of diamond [7-10].

Compared to their abundance, eclogites enclose diamond more often than ultramafic mantle-derived rocks because they contain more iron and have much greater redox buffering capacity than peridotites (especially highly refractory cratonic peridotite), which maintains precipitation of diamond during carbonate reduction [11]. Indeed, while inclusions in diamonds are predominantly peridotitic (P-type), eclogite-paragenesis (E-type) diamonds make up $>30 \%$ of inclusion-bearing diamonds, which far exceeds the estimated proportion of eclogite in the mantle lithosphere $[9,12,13]$. Typical eclogitic minerals are grossular-rich pyrope-almandine garnet and jadeite-rich omphacite ( \pm coesite, \pm kyanite, \pm rutile, \pm pyrrhotite), while olivine, orthopyroxene, Cr-diopside, pyrope garnet, chromite and Ni-rich sulfide are typical peridotitic phases.

Coesite is an important phase in the eclogitic diamond-forming medium [9] -it accounts for $22 \%$ of all eclogitic inclusions in kimberlite-hosted diamond from the Yakutian province [14]. Coesite, as well as diamond, documents the high-pressure history of its host rock and can be used as a geobarometer. The presence of coesite in some eclogites rules out their origin by direct crystallization of melts from the mantle, where garnet and pyroxenes are liquidus minerals and thus confirms the subduction-related origin of the eclogite protoliths [2,15]. High-Mg olivine (forsterite with \#Mg $>90$ ) is often found in mantle peridotite or is enclosed in micro- and macrodiamonds from kimberlite pipes, including in gem-quality crystals of different sizes. Previous comprehensive studies revealed relatively narrow ranges (compared to world-wide data of ultramafic olivine) of forsterite [ 90.2 to $95.4 \mathrm{~mol} \%$ ] and minor element concentrations ( $\mathrm{Ti}, \mathrm{Mn}, \mathrm{Ca}, \mathrm{Cr}, \mathrm{Ni}$ and $\mathrm{Co}$ ) in diamond-hosted olivine inclusions $[9,16]$.

In most cases, coesite and forsterite are not in equilibrium because $\mathrm{Mg}$-rich olivine is unstable in a high-silica environment (due to the peritectic formation of enstatite) and their coexistence is uncommon in mantle xenoliths. However, there is published evidence of diamond crystals containing mixed eclogitic-peridotitic mineral inclusions [17-25] and of an eclogitic xenolith with such diamonds [24]. Their origin is related to metasomatic processes. Carbonatite and silicate melt metasomatism are two major types of metasomatic alteration operating in the deep mantle. The presence of carbonate minerals as inclusions in rock-forming minerals (here: garnet and omphacite) or in the matrix of the xenoliths is the main diagnostic feature of carbonatite type metasomatism [26].

Lithospheric diamonds worldwide contain carbonate-rich, alkali-carbonatitic and saline-carbonatitic fluid/melt microinclusions [25,27-34]. Unfortunately, such microinclusions are dominantly found in fibrous diamonds which lack mineral inclusions, making it impossible to reliably determine their paragenesis (eclogitic or peridotitic). Crystalline carbonate inclusions are found both in lithospheric and sublithospheric diamonds [21,25,35-40]. Thus, carbonatitic, alkali-carbonatitic and saline-carbonatitic melts appear to be important mantle metasomatic agents involved in the formation of fibrous diamonds. Mantle xenoliths rarely enclose carbonate phases [41-48], though crystalline carbonates [26,49-51] and crystallized carbonated melts often occur as inclusions in xenolith minerals [52-56] and in macrocrysts/megacrysts/xenocrysts associated with kimberlites [57-61]. A wealth of implicit evidence indicates metasomatic effects of carbonated melts in 
mantle xenoliths [62-65]. The stability of carbonatitic and alkali-carbonatitic melts in the mantle is further supported by numerous high-pressure experimental studies [66-72].

Prior work on eclogite xenoliths from the Udachnaya kimberlite pipe has provided a wealth of information and not only advocates an origin by subduction of oceanic crust but also highlights the importance of subsequent metasomatism and its link to diamond formation [34,45,73,74]. The aim of this study is to reconstruct the metasomatic history of an extraordinary eclogite xenolith sample containing both coesite (eclogitic mineral) and olivine-orthopyroxene (peridotitic or pyroxenitic minerals), from mineralogy, element compositions and strontium isotope data. The sample offers a unique opportunity to observe the effect of eclogite interaction with an alkali-carbonatitic melt which induced a partial change from eclogitic to peridotitic paragenesis.

\section{Analytical Methods}

The mineral chemistry of the main phases was determined at the Sobolev Institute of Geology and Mineralogy (Analytical Center for Multi-Elemental and Isotope Research, Siberian Branch of the Russian Academy of Sciences, Novosibirsk, Russia), using a JEOL JXA-8100 electron microprobe and a TESCAN MIRA 3 LMU scanning electron microscope equipped with an Oxford Instruments INCA energy detector, $\mathrm{X}$-max $80 \mathrm{~mm}^{2}$. The scanning electron microscope was used for back-scattered electron (BSE) imaging and its X-ray energy dispersive system (EDS) for estimating element abundances. Quantitative electron microprobe (EMPA; JEOL JXA-8100) analyses of olivine, garnet and omphacite were performed at $20 \mathrm{kV}$ accelerating voltage, $100 \mathrm{nA}$ beam current and $2 \mu \mathrm{m}$ beam diameter, allowing quantification of minor and trace elements with detection limits of $128 \mathrm{ppm}$ for $\mathrm{P}, 30 \mathrm{ppm}$ for Ca, $113 \mathrm{ppm}$ for $\mathrm{Al}, 64 \mathrm{ppm}$ for $\mathrm{Ti}, 53 \mathrm{ppm}$ for $\mathrm{Mn}, 83 \mathrm{ppm}$ for $\mathrm{Ni}$ and $61 \mathrm{ppm}$ for $\mathrm{Cr}$ (further analytical details can be found in Reference [75]). Precision and accuracy were monitored using natural and synthetic standards that were measured at regular intervals during each analytical session. Results are reported in Table S1. Stoichiometry was checked based on calculated cations per formula unit after normalization, which further serves as a check on the quality of the analyses. The JEOL JXA-8100 electron microprobe was also used for chemical mapping at the operating conditions $20 \mathrm{kV}, 100 \mathrm{nA}$, with a counting time of $90 \mathrm{~s}$.

Raman spectra in the range from 50 to $4000 \mathrm{~cm}^{-1}$ were recorded using a LabRam $800 \mathrm{HR}$ (Horiba Jobin Yvon) spectrometer equipped with a Nd:YAG $532 \mathrm{~nm}$ laser (power $\times 30 \mathrm{~mW}$; beam diameter 1-2 $\mu \mathrm{m}$ ) and an Olympus BX51 microscope (IGM SB RAS). The Raman spectra were recorded at room temperature in the backscattering geometry with an Olympus MPlan $100 \times$ objective lens $(0.37 \mathrm{~mm}$ working distance, 0.9 numerical aperture).

Trace elements in garnet and clinopyroxene were acquired at the Institute for Geosciences at Goethe-University Frankfurt with a Thermo Scientific ELEMENT XR inductively-coupled plasma mass spectrometer (ICPMS) linked to a RESOlution (Resonetics) $193 \mathrm{~nm}$ ArF Excimer Laser (CompexPro 102, Coherent), using reference material NIST612 for sensitivity calibration and Si (as previously determined by electron microprobe) for quantification (see [76] for further details and data acquisition and reduction). Results are reported in Table S2A, including those for basalt glass BIR-1G, which was measured as an unknown to monitor precision and accuracy.

The same laser device was used with a Thermo Scientific NEPTUNE PLUS multi-collector (MC) ICPMS at Goethe-University, Frankfurt, Germany, to measure ${ }^{87} \mathrm{Sr} /{ }^{86} \mathrm{Sr}$ in clinopyroxene along with a larger suite of samples, following the procedure in Reference [77]. Briefly, the set-up included the use of Faraday Cups in static collection mode, a spot size of $128 \mu \mathrm{m}, 10 \mathrm{~Hz}$ repetition rate and laser energy of 5-6 J cm$~^{-1}$. Accuracy was monitored using a variety of standards measured as unknowns: (1) The in-house standard plagioclase MIR-1 yielded ${ }^{87} \mathrm{Sr} /{ }^{86} \mathrm{Sr}(0.703080 \pm 0.0000091 \sigma$, $n=5)$ compared to the TIMS-derived value ${ }^{87} \mathrm{Sr} /{ }^{86} \mathrm{Sr}(0.703096 \pm 0.000050)$; (2) USGS glass BCR-2 yielded $0.704959 \pm 0.000019(n=6)$ compared to the GeoREM preferred value of $0.705003 \pm 0.00004$; (3) USGS glass BHVO-2 yielded $0.703453 \pm 0.000020(n=6)$ compared to the GeoREM preferred value of $0.703469 \pm 0.000007$ (http://georem.mpch-mainz.gwdg.de). Results are reported in Table S2B. 


\section{Geological Setting}

The Udachnaya pipe belongs to the Daldyn-Alakit field of the Yakutian kimberlite province in the Siberian craton. The pipe consists of eastern and western bodies and is hosted by Ordovician and Devonian sedimentary rocks (limestones, dolomites, marls, siltstones, mudstones, sandstones and limy conglomerates) [78]. The Udachnaya kimberlite results from Middle Paleozoic activity ( $367 \pm 5 \mathrm{Ma})$. The eastern and western bodies differ in mineralogy, petrography and in the alteration degree of xenoliths [78,79]. Mantle xenoliths from the Udachnaya-West kimberlite are commonly strongly serpentinized, while those of Udachnaya-East are mainly fresh and highly diverse in mineralogy and composition.

\section{Results}

\subsection{Petrography and Major-Element Composition}

Sample Uv-537, a coesite-bearing diamondiferous eclogitic xenolith with a $7.5 \mathrm{~cm}$ in maximum length, was collected from non-serpentinized ultra-fresh kimberlite in the Udachnaya-East open-pit mine $[79,80]$. It is a medium-grained eclogite with a massive structure and a granoblastic texture (Figure 1) consisting of $60 \mathrm{vol} \%$ omphacite, $35 \mathrm{vol} \%$ garnet and $5 \mathrm{vol} \%$ coesite/quartz.
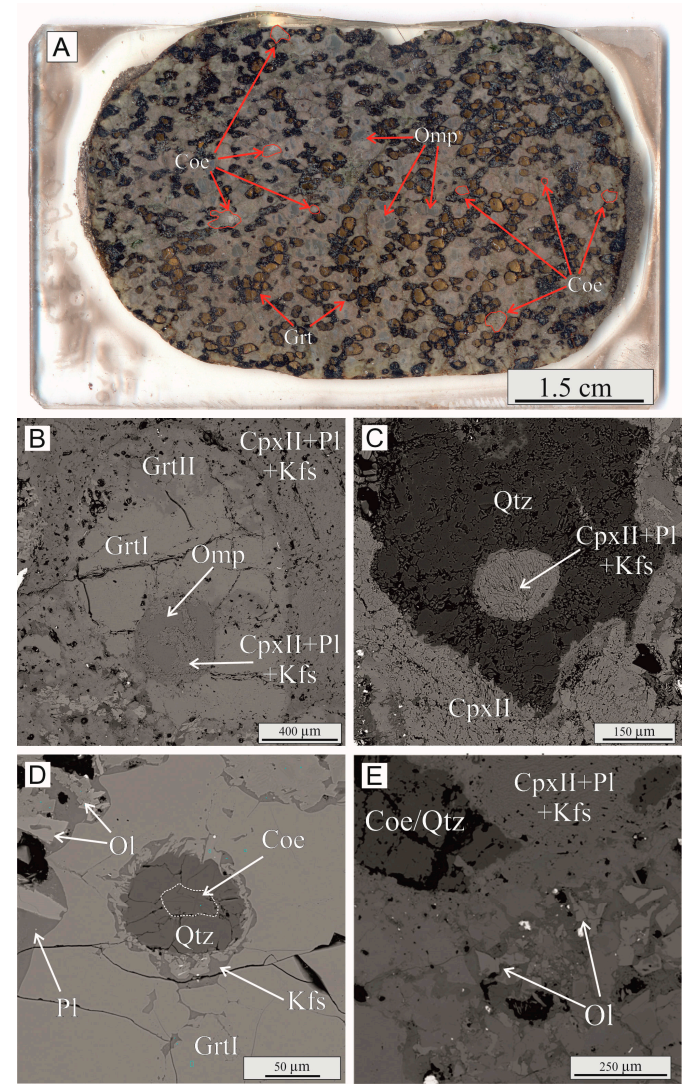

Figure 1. Photomicrograph of polished section (A) and BSE images (B-E) of sample Uv-537. (A): xenolith composed of garnet (Grt), omphacite (Omp, i.e., CpxI) and coesite/quartz (Coe/Qtz); (B): garnet grain (Grt I-garnet core, Grt II-garnet rim) with inclusions of primary clinopyroxene and secondary mineral assemblages after omphacite (CpxII-secondary clinopyroxene, Pl-plagioclase, Kfs-K-feldspar); (C): quartz (Qtz) grain with an inclusion of secondary clinopyroxene, plagioclase and K-feldspar; (D): coesite (Coe) inclusion in garnet with quartz rim and a secondary mineral assemblage (Ol-olivine);

(E): interstitial olivine and coesite/quartz grains. 
Primary clinopyroxene grains are anhedral and likewise heavily fractured, of grey-green color with a bluish hue and 0.1 to $1.6 \mathrm{~mm}$ in size, with inclusions of garnet and coesite/quartz (Figure 1). Primary clinopyroxene is omphacite [81] with its composition $\left(\mathrm{Jd}_{28-29.5} \mathrm{Di}_{44.5-45} \mathrm{Hd}_{12.5-13}\right)$ corresponding to Group B eclogite [82]. Omphacite grains are homogeneous, with up to $0.72-1.11 \mathrm{wt} \% \mathrm{~K}_{2} \mathrm{O}$ and $0.72-0.73$ $\mathrm{wt} \% \mathrm{TiO}_{2}$ (Table 1 and Table S1). Clinopyroxene enclosed in the garnet core is compositionally identical to rock-forming omphacite (= CpxI).

Table 1. Representative major-element concentrations (wt\%; EPMA analyses) for garnet core-rim (Grt) and omphacite (Omp) in diamondiferous coesite-bearing eclogite xenolith from the Udachnaya kimberlite pipe.

\begin{tabular}{ccccccc}
\hline Grt & Grt (core) & Grt (core) & Grt (rim) & Grt (rim) & Omp & Omp \\
\hline $\mathrm{SiO}_{2}$ & 40.9 & 41.2 & 42.1 & 42.0 & 55.8 & 55.9 \\
$\mathrm{TiO}_{2}$ & 0.68 & 0.72 & 0.42 & 0.43 & 0.73 & 0.73 \\
$\mathrm{Al}_{2} \mathrm{O}_{3}$ & 21.8 & 21.9 & 22.1 & 22.3 & 7.9 & 8.0 \\
$\mathrm{Cr}_{2} \mathrm{O}_{3}$ & 0.04 & 0.03 & 0.08 & 0.06 & 0.04 & 0.04 \\
$\mathrm{FeO}$ & 16.0 & 16.1 & 12.4 & 12.7 & 5.5 & 5.4 \\
$\mathrm{MnO}$ & 0.46 & 0.46 & 0.38 & 0.40 & 0.11 & 0.08 \\
$\mathrm{MgO}$ & 13.1 & 13.3 & 16.8 & 16.6 & 10.8 & 10.7 \\
$\mathrm{CaO}$ & 6.8 & 6.8 & 5.8 & 5.8 & 14.5 & 14.4 \\
$\mathrm{Na} 2 \mathrm{O}$ & 0.23 & 0.22 & 0.13 & 0.13 & 3.9 & 3.7 \\
$\mathrm{~K}_{2} \mathrm{O}$ & 0.00 & 0.01 & 0.00 & 0.00 & 0.80 & 1.1 \\
$\mathrm{Total}$ & 100.1 & 100.8 & 100.2 & 100.4 & 100.2 & 100.1 \\
$\mathrm{Si}$ & 3.0 & 3.0 & 3.0 & 3.0 & 2.0 & 2.0 \\
$\mathrm{Ti}$ & 0.04 & 0.04 & 0.02 & 0.02 & 0.02 & 0.02 \\
$\mathrm{Al}$ & 1.9 & 1.9 & 1.9 & 1.9 & 0.33 & 0.34 \\
$\mathrm{Cr}$ & 0.00 & 0.00 & 0.00 & 0.00 & 0.00 & 0.00 \\
$\mathrm{Fe}$ tot & 0.93 & 0.93 & 0.66 & 0.69 & 0.16 & 0.16 \\
$\mathrm{Mn}$ & 0.03 & 0.03 & 0.02 & 0.02 & 0.00 & 0.00 \\
$\mathrm{Mg}$ & 1.4 & 1.5 & 1.8 & 1.8 & 0.58 & 0.57 \\
$\mathrm{Ca}$ & 0.54 & 0.53 & 0.45 & 0.45 & 0.56 & 0.55 \\
$\mathrm{Na}$ & 0.03 & 0.03 & 0.02 & 0.02 & 0.27 & 0.26 \\
$\mathrm{~K}$ & 0.00 & 0.00 & 0.00 & 0.00 & 0.04 & 0.05 \\
$\mathrm{Total}$ & 8.0 & 8.0 & 8.0 & 8.0 & 4.0 & 4.0 \\
\hline
\end{tabular}

Garnet occurs as heavily fractured 0.5 to $1 \mathrm{~mm}$ reddish-orange round grains that enclose omphacite and coesite/quartz (Figure 1). It has a homogeneous core ( $\operatorname{Prp}_{48} \operatorname{Gross}_{14} \mathrm{Alm}_{31} \mathrm{And}_{3}$ ), with its composition corresponding to Group B eclogite (Grt I) (classification of Coleman [83]; Table 1; Table S1) and a sharply defined, compositionally distinct $\operatorname{Prp}_{60.3-62.2}$ Gross $_{8.6-10.6-} \mathrm{Alm}_{22.3-23.6} \mathrm{And}_{3.2-4.6}$ rim (Grt II) (Figure 2). MgO concentrations increase from $\sim 13.2 \mathrm{wt} \%$ in the core to $\sim 18.8 \mathrm{wt} \%$ in the rim, whereas $\mathrm{FeO}$ decreases correspondingly from $\sim 16.2 \mathrm{wt} \%$ to $\sim 12.6 \mathrm{wt} \%$; $\mathrm{CaO}$ and $\mathrm{TiO}_{2}$ likewise decrease rimward from $\sim 6.8$ and $0.68-0.72 \mathrm{wt} \%$ to $\sim 5.0-5.8$ and $0.30-0.44 \mathrm{wt} \%$, respectively; $\mathrm{Na}_{2} \mathrm{O}$ is very high in the core (0.22-0.24 $\mathrm{wt} \%)$ but drops to $0.11-0.13 \mathrm{wt} \%$ in the rim; $\mathrm{Cr}_{2} \mathrm{O}_{3}$ does not exceed $0.1 \mathrm{wt} \%$ throughout the grains.

White-grey quartz pseudomorphs after coesite (Figure 1D and Figure 5A) were found in the intergranular space ( 0.2 to $1.5 \mathrm{~mm}$ ) or enclosed in garnet and omphacite (up to $200 \mu \mathrm{m}$ in garnet). Representative Raman spectra of coesite and quartz shown in Figure 3.

Primary omphacite is largely replaced by a clinopyroxene-plagioclase-K-feldspar symplectite, with the size of symplectite grains increasing from $\sim 10$ to $100 \mu \mathrm{m}$ off relict primary omphacites. Secondary clinopyroxene exists as spongy-textured milky-white irregularly-shaped grains. It is distinctly heterogeneous $\left(\mathrm{Jd}_{19.8-34.8} \mathrm{Di}_{48-63} \mathrm{Hd}_{4.8-8.5} \mathrm{En}_{3.5-8.4}\right)$ and makes up the series "diopside-augite-augite-aegirine-pigeonite" according to the classification of Morimoto [81]. The chemical composition is highly variable both within a single symplectite (neighboring grains) and within the sample (Figure 4). $\mathrm{TiO}_{2}$ contents reach as high as $0.8 \mathrm{wt} \%$ (Table S1). Kelyphitic assemblages 
(50 to $200 \mu \mathrm{m}$ thick) around garnet grains consist of secondary clinopyroxene, plagioclase, K-feldspar, amphibole, spinel and sulfide (pentlandite and pyrrhotite).

Plagioclase has an albitic composition with $\mathrm{Ab}_{92.2} \mathrm{An}_{5.1} \mathrm{Or}_{2.7}$ and $\mathrm{Ab}_{82} \mathrm{An}_{16.2} \mathrm{Or}_{1.8}$ in coarse and fine grains, respectively. Within-grain variations are small but compositions of different grains within a single sample are variable. Compositions of K-feldspar within the symplectite are markedly size-dependent: $\mathrm{Or}_{85.6} \mathrm{Ab}_{10.3} \mathrm{An}_{4.1}$ in coarse grains and $\mathrm{Or}_{89.3} \mathrm{Ab}_{10.7}$ in fine grains (Table S1).

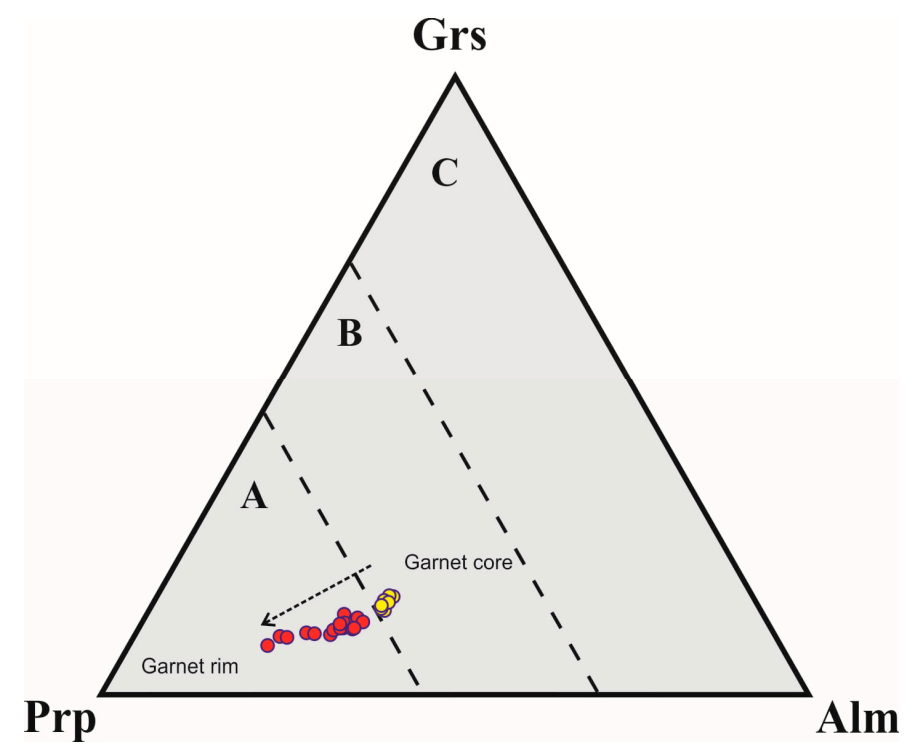

Figure 2. Composition of garnet core (yellow circles) and rim (red circles) from Uv-537 eclogite, from the Udachnaya kimberlite pipe, in ternary diagram (A, B, C) for classification of eclogites [83] (Grs-grossular; Prp-pyrope; Alm-almandine). Dash arrow indicates change of composition of garnet from core (Grt I) to rim (Grt II).

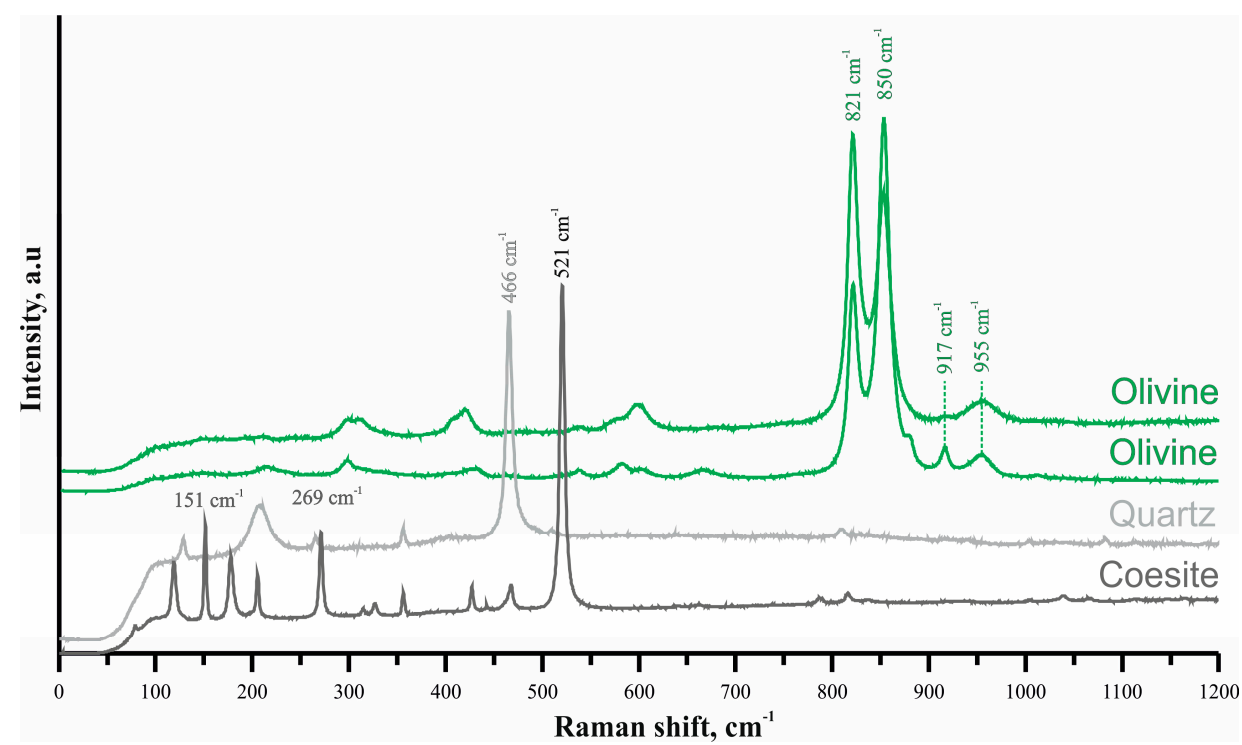

Figure 3. Representative Raman spectra of olivines, quartz and coesite from Uv-537 eclogite. 


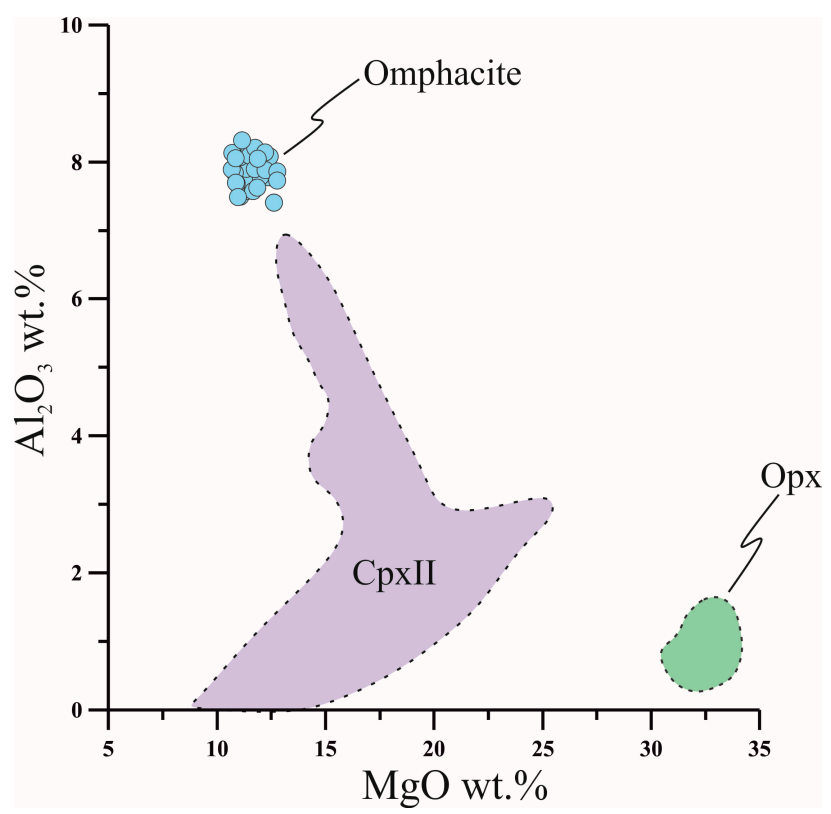

Figure 4. $\mathrm{Al}_{2} \mathrm{O}_{3}$ vs. $\mathrm{MgO}(\mathrm{wt} \%$ ) in primary clinopyroxene (omphacite = $\mathrm{CpxI}$ ), secondary clinopyroxene (CpxII) and secondary orthopyroxene (Opx).

Olivine grains occur as elongated crystals, $30-40 \mu \mathrm{m}$ wide and up to $200 \mu \mathrm{m}$ long, in the intergranular space between rock-forming garnet and omphacite (Figures 1, 5 and 6). Zoned olivine grains have a relatively Mg-rich core (Fo\# 80-83) and an Fe-enriched rim (Fo\# 69-74) (Figure 7; Table S1). According to EPMA data, all olivines bear high contents of impurities: $\mathrm{P}_{2} \mathrm{O}_{5}(0.01-0.03$ and $0.20-0.46 \mathrm{wt} \%$ in core and rim, respectively), $\mathrm{MnO}(0.41-1.55 \mathrm{wt} \%$ and $0.52-0.67 \mathrm{wt} \%), \mathrm{CaO}(0.04-0.36$ and $0.19-0.37 \mathrm{wt} \%)$ and $\mathrm{Al}_{2} \mathrm{O}_{3}(0.01-0.02$ and $0.03-0.13 \mathrm{wt} \%)$ (Table S1), whereas the concentrations of $\mathrm{NiO}$ and $\mathrm{TiO}_{2}$ do not exceed $0.03 \mathrm{wt} \%$ each. The Raman spectra of individual olivine grains show distinct major peaks at 819 and $850 \mathrm{~cm}^{-1}$ and less pronounced peaks at 536 and $915 \mathrm{~cm}^{-1}$, which are typical olivine Raman peaks (Figure 3).

Orthopyroxene (enstatite [81]), up to $0.8 \mathrm{~mm}$, was found intergrown with high-Mg olivine ( $\mathrm{Fo}_{83}$ and $\# \mathrm{Mg}_{84-86}$ ) in the interstitial space (Figure 5E). It is in immediate contact with other secondary phases, such as phlogopite, sodalite, spinel and CpxII (Figure S1). Its chemical composition is mostly homogeneous, with up to $0.5 \mathrm{wt} \% \mathrm{TiO}_{2}$ and $0.3 \mathrm{wt} \% \mathrm{Cr}_{2} \mathrm{O}_{3}$ (Table S1B).

Sulfides (pentlandite, pyrrhotite and djerfisherite) occur in the intergranular space as $0.2-2 \mathrm{~mm}$ grains (Figure 5B). Phlogopite is a secondary mineral occurring as 20 to $40 \mu \mathrm{m}$ grains in the intergranular space together with the secondary mineral assemblage of CpxII-plagioclase-sodalite. Phlogopite was found enclosed in olivine grains or intergrown with orthopyroxene (Figure 5E). Euhedral crystals of spinel $\left(\mathrm{MgAl}_{2} \mathrm{O}_{4}\right)$ with a significant percentage of the hercynite (\#38-50) end-member $\left(\mathrm{FeAl}_{2} \mathrm{O}_{4}\right)$ were identified in kelyphitic rims around garnets and in the intergranular space together with olivines. Sodalite $(100 \mu \mathrm{m})$ was detected at the garnet-symplectite boundary. Chemical analyses of phlogopite, spinel and sodalite are listed in Table S1B.

Diamond aggregates have flattened/elongated habits and are located in the intergranular space between rock-forming garnet and omphacite (Figure 5F). In general, they occur as numerous randomly oriented cubic-octahedral crystals of variable sizes (up to $2 \mathrm{~mm}$ ) and belong to variety I (octahedral crystal with flat-faces, sharp edges and corners) in the classification of Orlov [92]. The diamond crystals have numerous negative-oriented triangular etch pits on (111) faces with a distinct laminar structure. 

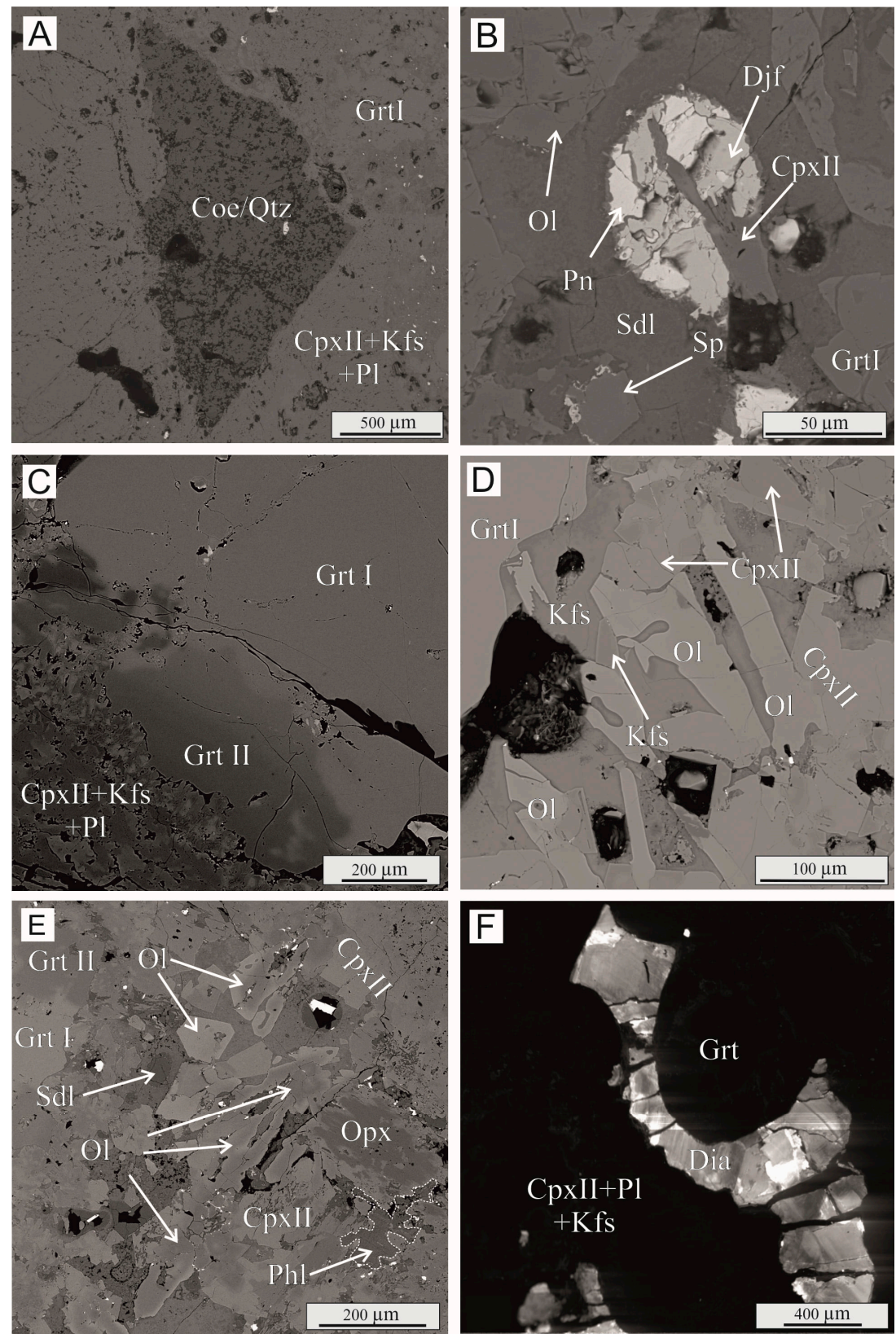

Figure 5. Images of sample Uv-537. (A): coesite grain with quartz rim (Coe/Qtz) in intergranular space (Grt I—garnet core, CpxII—secondary clinopyroxene, Pl—plagioclase, Kfs-K-feldspar); (B): sulfides (Pn—pentlandite, Djf-djerfisherite) with secondary clinopyroxene, sodalite (Sdl), spinel (Sp) and olivine (Ol) in intergranular space); (C): garnet grain with prominent core to rim (Grt II) zoning; (D): olivine grains with secondary minerals in intergranular space; (E): orthopyroxene-olivine intergrowth with secondary mineral assemblages (Opx-orthopyroxene, Phl一phlogopite) between garnet and symplectite after omphacite; (F): boundary between diamond (Dia) [84] and symplectite after omphacite. (A-E): BSE images, (F): cathodoluminescence topogram. 

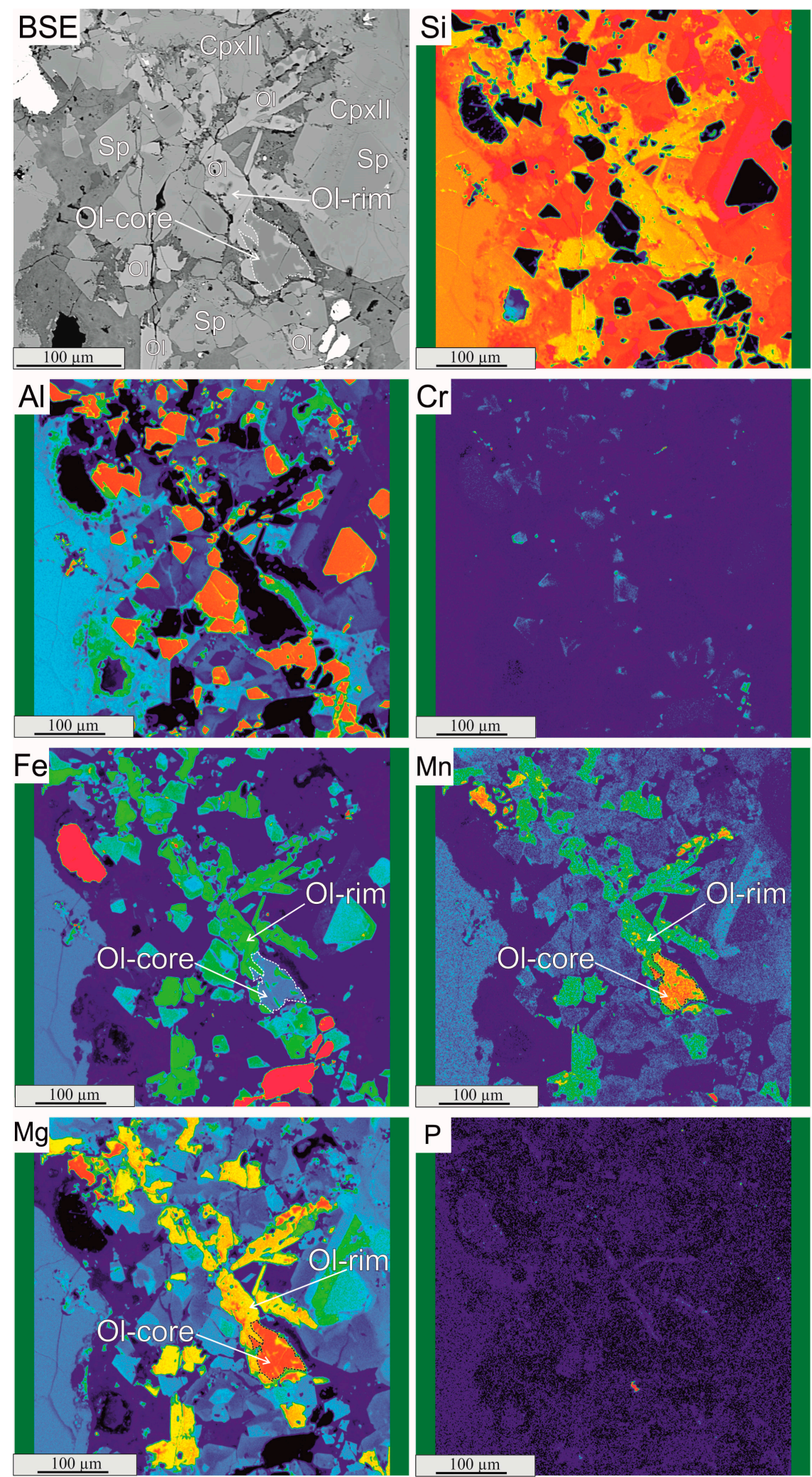

Figure 6. Back-scattered electron (BSE) image and elemental maps of $\mathrm{Si}, \mathrm{Al}, \mathrm{Cr}, \mathrm{Fe}, \mathrm{Mn}, \mathrm{Mg}$ and $\mathrm{P}$ in the olivine-bearing assemblage from Uv-537 eclogite. Sp—spinel; Ol—olivine; CpxII—diopside. 

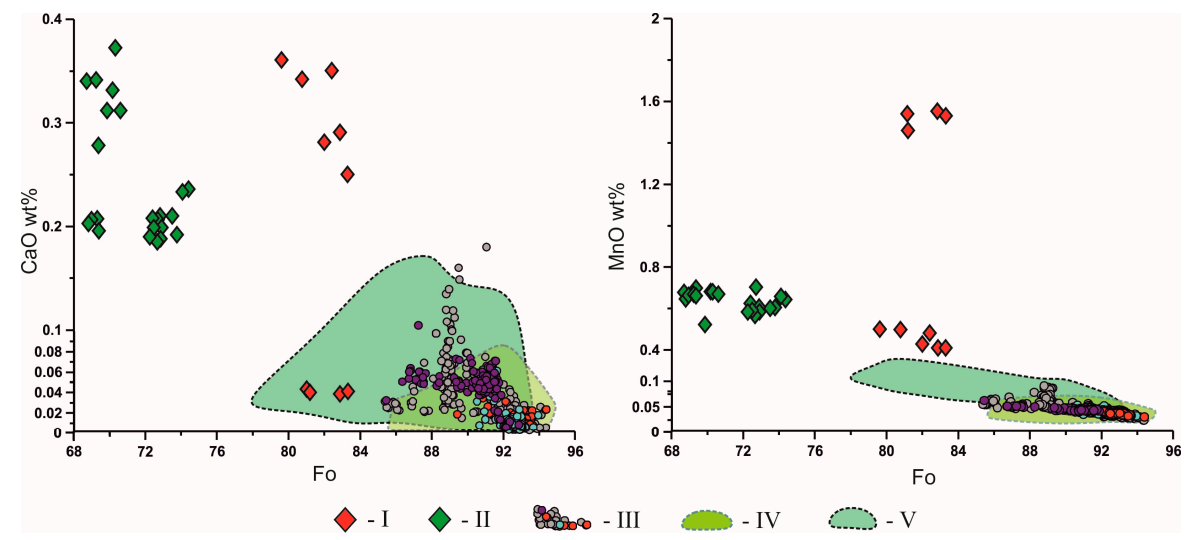

Figure 7. Concentrations of $\mathrm{CaO}$ and $\mathrm{MnO}(w \mathrm{t} \%)$ vs. Forsterite $(\mathrm{Fo})$ component in olivine from sample Uv-537 (according to EPMA). Roman numerals stand for: $\mathbf{I}$ and II = core and rim of intergranular olivine from studied eclogite xenolith; III = olivine composition from peridotite xenoliths (Udachnaya database, $n=694)[16,55,62,85-87] ; \mathbf{I V}=$ olivine inclusions in diamond $(n=665)$ [16]; $\mathbf{V}=$ olivine from kimberlites $(n=1179)$ [88-91].

\subsection{Trace-Element and Isotopic Composition}

\subsubsection{Clinopyroxene}

Omphacite rare earth elements (REE) patterns show a humped shape with progressive enrichment from $\mathrm{La}$ to $\mathrm{Eu}$ followed by linear decrease to heavy REE (HREE) (Figure 8). La $(\mathrm{N}$ denotes normalization to chondrite [93]) ranges from 3 to 3.3, Eu peaks at $\sim 10$ and $\mathrm{Yb}_{\mathrm{n}}$ is within 1 to 1.2. The $\mathrm{La}_{n} / \mathrm{Pr}_{\mathrm{n}}$ ratio is $0.6, \mathrm{Gd}_{n} / \mathrm{Lu}_{n}$ varies from 9 to 11.7 and $\mathrm{Ce}_{\mathrm{n}} / \mathrm{Eu}_{\mathrm{n}}$ is 0.3 . Omphacite contains up to 447-470 ppm Sr and 1.7-2.0 ppm Zr. The contents of transition metals are low, with 116-119 ppm $\mathrm{Ni}, 49.7-52.6 \mathrm{ppm} \mathrm{Zn}$ and 4.7-6.4 ppm Cu (Table S2A). The average in situ strontium isotope ratio $\left({ }^{87} \mathrm{Sr} /{ }^{86} \mathrm{Sr}\right)$ in omphacite is $0.703630( \pm 0.0000471 \sigma, n=7)$ and ${ }^{87} \mathrm{Rb} /{ }^{86} \mathrm{Sr}$ is low $(0.0013)$ (Table S2B).
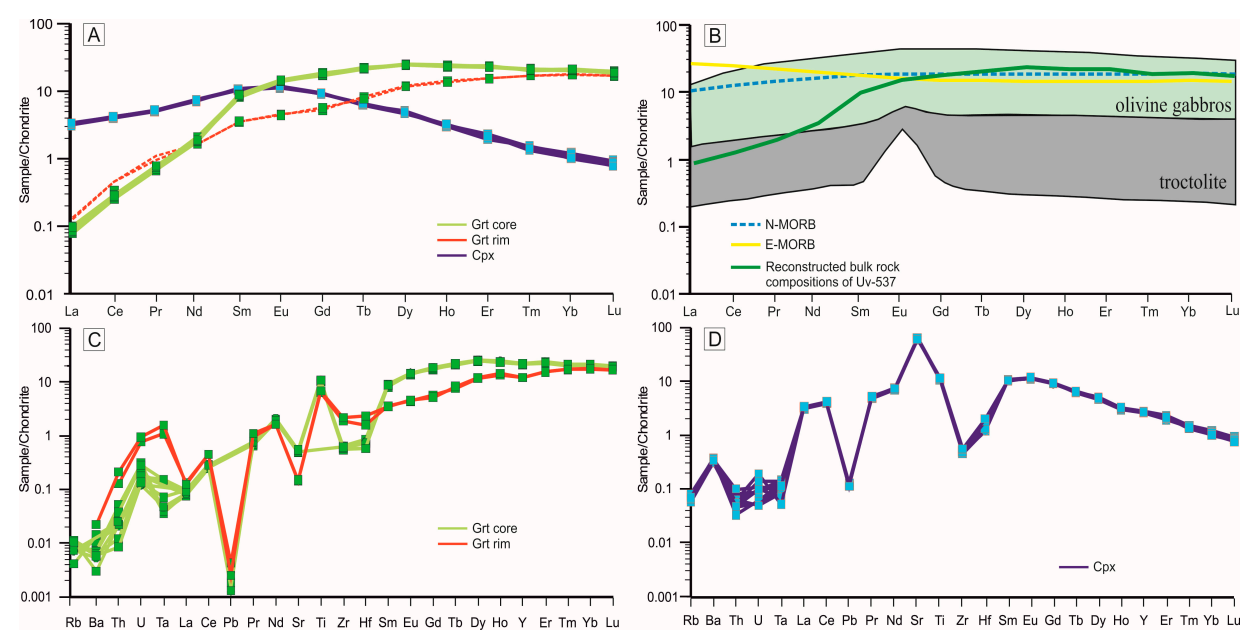

Figure 8. Chondrite-normalized rare earth elements (REE) [93] (A) and extended trace element patterns (C,D) of clinopyroxene and garnet (core and rim) from Uv-537 eclogite. Panel (B) shows bulk rock composition reconstructed. The average N-MORB and E-MORB REE compositions [94] are shown for reference as well as the range of troctolite compositions from Pito Deep, Pacific ridge [95] and the compositional field of olivine gabbros from the MARK region, mid- Atlantic ridge [96].

\subsubsection{Garnet}

The REE patterns of garnet cores show HREE enrichment ( $>20$ chondrite units) with a very gentle decrease to MREE (20-10 chondrite units), significant depletion in light REE (LREE) (2-0.1 chondrite 
units) (Figure 8) and a moderate Eu anomaly $\left(\mathrm{Eu}^{*}=\left(\mathrm{Eu}_{\mathrm{n}} / \sqrt{ } \mathrm{Sm}_{\mathrm{n}}{ }^{*} \mathrm{G} \mathrm{d}_{\mathrm{n}}\right)\right)$ of 1.1. The $\mathrm{Lu}_{\mathrm{n}} / \mathrm{Gd}_{\mathrm{n}}$ and $\mathrm{Sm}_{\mathrm{n}} / \mathrm{La}_{\mathrm{n}}$ ratios are 1 and 93, respectively. The chondrite-normalized $\mathrm{Zr}_{n} / \mathrm{Hf}_{n}$ ratio is $<1$, with $0.6 \mathrm{Zr}_{n}$ and $0.7 \mathrm{Hf}_{\mathrm{n}}$; the $\mathrm{Zr} / \mathrm{Y}$ is 0.07 , with $34 \mathrm{ppm} \mathrm{Y}$. The contents of $\mathrm{Nb}$ and $\mathrm{Ta}$, as well as $\mathrm{Ba}$, are mostly below the detection limit. Sr abundances is $3.8 \mathrm{ppm}$, while that of $\mathrm{Ni}$ and $\mathrm{V}$ is 27 and $137 \mathrm{ppm}$, respectively (Table S2A).

Garnet rims exhibit a progressive decrease from HREE to LREE (Figure 8), and medium REE (MREE) contents substantially lower than in the cores: $3.5 \mathrm{Sm}_{n}, 4.4 \mathrm{Eu}_{\mathrm{n}}$ and $5.6 \mathrm{Gd}_{n} ; \mathrm{Nd}_{\mathrm{n}}$ is 1.6; the element ratios are $\mathrm{Lu}_{n} / \mathrm{Gd}_{\mathrm{n}}=3, \mathrm{Sm}_{\mathrm{n}} / \mathrm{La}_{\mathrm{n}}=27, \mathrm{Gd} / \mathrm{Yb}=0.3, \mathrm{Zr} / \mathrm{Y}=0.43$. The concentrations of $\mathrm{Ba}$, $\mathrm{Ta}$ and $\mathrm{Rb}$ are below detection limit. $\mathrm{Ni}$ and $\mathrm{Sr}$ are 23 and $1 \mathrm{ppm}$, respectively. Some trace elements show prominent core-rim zoning, with respective element contents in core and rim of 2.3 and $8 \mathrm{ppm}$ $\mathrm{Zr}, 34$ and $19 \mathrm{ppm} \mathrm{Y,} 3.9$ and $1 \mathrm{ppm} \mathrm{Sr}$, and below detection limit and $0.2 \mathrm{ppm} \mathrm{Hf} ; \mathrm{Zr} / \mathrm{Y}$ in the rim is 6 times higher than in the core (Table S2A).

\subsection{Geothermobarometry}

In the Uv-537 xenolith, primary rock-forming minerals (garnet, omphacite and coesite) enclosed in one another bear signatures of syngenetic growth at least within the coesite stability field. The presence of diamond indicates a high pressure of $>4 \mathrm{GPa}$ at $950-1000{ }^{\circ} \mathrm{C}$. The concentrations of $\mathrm{K}_{2} \mathrm{O}-\mathrm{TiO}_{2}$ in omphacite and $\mathrm{Na}_{2} \mathrm{O}-\mathrm{TiO}_{2}$ in garnet, which are commonly high in ultrahigh-pressure host rocks [12, 97-100], are rather high in the Uv-537 sample: up to $1.11 \mathrm{wt} \%$ and $0.24 \mathrm{wt} \%$, respectively. According to calculations, omphacite with such $\mathrm{K}_{2} \mathrm{O}$ contents forms at 6 GPa [101]. The P-T conditions of eclogite residence in the cratonic lithosphere were reconstructed using the garnet-clinopyroxene geothermometer of Reference [102] and geobarometer of Reference [103]. The garnet core/primary omphacite yielded temperatures of $1200 \pm 50^{\circ} \mathrm{C}$ (at $6.2 \pm 0.2 \mathrm{GPa}$ ), that is, within the diamond stability field (along a geothermal gradient corresponding to a surface heat flux of $40 \mathrm{~mW} \cdot \mathrm{m}^{-2}$, appropriate for the lithospheric mantle under Udachnaya [104]).

\subsection{Bulk Rock Composition}

The bulk rock composition of the Uv-537 sample cannot be measured because of its small size and effects of kimberlite infiltration, but can be reconstructed from the chemical composition weighted by modal ratios of its primary minerals, with removed effects of the kimberlite melt, as is common procedure of mantle eclogite xenoliths $[6,105,106]$. The percentages of minerals were calculated in a thin section, assuming that the relative percentages are constant throughout the sample. The primary bulk composition of Uv-537 was reconstructed using the observed mineralogy of 35\% garnet, $60 \%$ clinopyroxene and $5 \%$ coesite/quartz, without secondary minerals in the intergranular space (olivine, mica, etc.). The density of individual components was calculated proceeding from their relative percentages in minerals (almandine, andradite, grossular and pyrope in garnet and jadeite, diopside and hedenbergite in clinopyroxene, with almandine 4.32 ; andradite 3.85 ; grossular 3.59; pyrope 3.58, jadeite 3.25 ; diopside 3.25 , hedenbergite $3.56 \mathrm{~g} / \mathrm{cm}^{3}$ ).

The reconstructed bulk composition of eclogite is similar to gabbroic cumulates, especially in the contents of $\mathrm{MgO}$ and $\mathrm{CaO}$ [2] (Table S3). The REE spectrum is flat from Sm to HREE while LREE are notably lower. The moderate positive Eu anomaly $\left(\mathrm{Eu}^{*}=1.1\right)$ corresponds to that in mafic gabbroic cumulates from more or less fractionated MORB-type melts [107].

\section{Discussion}

\subsection{Formation of a Mixed Paragenesis during Metasomatism}

A diamond crystal with fluid/mineral inclusions provides a snapshot of its crystallization environment. Coesite and olivine inclusions are considered indicator minerals, respectively, of eclogitic or peridotitic origin of diamond [11]. Coexistence of coesite as an $\mathrm{SiO}_{2}$-phase (eclogitic suite) and harzburgitic garnet or olivine (peridotitic suite) inclusions within a single diamond crystal record 
repeated stages of diamond growth in a changeable chemical environment $[22,24,108]$. The conditions leading to formation of mixed eclogite-peridotite parageneses of inclusions, known from some kimberlite pipes [17-24], are preserved in the chemically inert diamond host. In contrast, they can be fully erased in the diamond substrate (host rock) by the subsequent evolution and homogenization due to diffusion at high temperatures in the mantle or catalyzed by interaction with fluids or melts.

Diamonds from a bimineralic eclogitic xenolith in the Udachnaya kimberlite pipe studied by Ragozin et al. [24] enclose olivine, calcite and intergrown coesite-clinopyroxene. However, the location of these inclusions with respect to the diamond growth zones remains poorly constrained. Yet, no coesite or olivine were found among the rock-forming and accessory minerals of the host xenolith. According to the mineral chemistry of primary clinopyroxene and garnet, the analyzed eclogite belongs to Group A. The origin of this particular eclogite was attributed [24] to C-O-H metasomatic transformation of peridotite.

Wang [23] revealed four olivine, one sanidine and one coesite inclusions in a diamond crystal from a kimberlite in China and hypothesized that diamond originated in an eclogitic host representing subducted oceanic crust later entrained in a mantle plume, followed by extensive eclogite partial melting at peridotite subsolidus conditions. This made it possible to transport the diamond into the peridotite matrix where it subsequently captured peridotitic mineral inclusions during renewed growth from fluids.

A mixed paragenesis of $\mathrm{SiO}_{2}$, olivine and harzburgitic garnet inclusions was also reported from diamond in the River Ranch kimberlite (Zimbabwe) [108] and interpreted [22] as evidence of peridotite carbonation. This reaction was described in [109] as leading to the formation of $\mathrm{SiO}_{2}$ - undersaturated basic magma compositions, precluding the formation of $\mathrm{SiO}_{2}$ in peridotite. However, strong physicochemical gradients enabling sequential growth of eclogitic and peridotitic minerals might occur locally in highly carbonated metasomatic veins or in a block of subducted sediments [110].

\subsection{Petrogenesis of Coesite-bearing Eclogite Uv-537}

\subsubsection{Protolith Reconstruction and Metamorphic Evolution}

The bulk rock composition of the Uv-537 eclogite was reconstructed from the garnet core and omphacite, which correspond to the rock-forming minerals in this rock. According to Jacob [2], the presence of coesite implies a low-pressure protolith, as does the presence of moderate positive Eu anomalies $\left(\mathrm{Eu}^{*}=1.1\right)$ requiring plagioclase accumulation. We therefore suggest that $\mathrm{Uv}-537$ eclogite formed by subduction of lower oceanic crust composed of gabbronorite or olivine gabbro. Also consistent with a low-pressure protolith are the flat chondrite-normalized MREE-HREE abundances, which are similar to those of modern oceanic crust formed by garnet-absent partial melting of peridotite at spreading ridges, followed by crystallization of olivine, plagioclase and clinopyroxene [3]. The contents of $\mathrm{Ni}$ in the reconstructed bulk compositions (44 ppm) are much lower than in primary mantle melts ( $\geq 320 \mathrm{ppm}$ ) [111] and lower than in group A eclogite (493-659 ppm) [82], that is, the protolith of Uv-537 may have contained little olivine, although some Ni may be stored in sulfide that was not considered in bulk rock reconstruction of the eclogites. Bearing in mind that the behavior of $\mathrm{V}$ during partial melting and differentiation is strongly redox-dependent [112], the elevated $\mathrm{V}$ content of $157 \mathrm{ppm}$ in the bulk eclogite may reflect a high proportion of cpx in the protolith. A cumulate protolith containing a high proportion of plagioclase is indicated by the positive Eu anomaly in the reconstructed whole rock as well as the extremely low ${ }^{87} \mathrm{Rb} /{ }^{86} \mathrm{Sr}$ of omphacite (0.0013), which controls both $\mathrm{Rb}$ and $\mathrm{Sr}$ abundances in the bulk rock. This reflects strong $\mathrm{Sr}$ partitioning into accumulating plagioclase and exclusion of highly incompatible $\mathrm{Rb}$.

This cumulate protolith was subsequently subducted and underwent metamorphism. Some eclogites from the Udachnaya kimberlite show LREE depletion and HREE enrichment in the reconstructed bulk compositions, possibly resulting from partial melting [106], presumably during 
or after subduction. As suggested in [113], partial melting reaches the highest degree in basaltic eclogite derived from upper oceanic crust but is insignificant in eclogites derived from gabbros in the deep oceanic crust. Alternatively, the low LREE/HREE are inherited from the crustal protolith, similar to the REE patterns found in the cumulate section of ophiolites [96]. Indeed, the presence of accessory coesite in Uv-537 restricts the melt fraction to 13\% [114], although loss of a lower melt fraction cannot be discounted. The available experimental data show that pressure is a key control of high- $\mathrm{K}$ clinopyroxene formation [97]. Thus, the high contents of $\mathrm{K}_{2} \mathrm{O}$ in omphacite and $\mathrm{Na}_{2} \mathrm{O}$ in garnet (0.7-1.1 $\mathrm{wt} \% \mathrm{~K}_{2} \mathrm{O}$ and $0.25 \mathrm{wt} \% \mathrm{Na}_{2} \mathrm{O}$, respectively) indicate a deep-seated origin of their host rocks [12] corresponding to ultra-high pressure conditions, as also suggested by the high calculated pressure of $>6 \mathrm{GPa}$ and the presence of diamond.

\subsubsection{Formation of Olivine and Associated Secondary Minerals}

Olivine in eclogite xenoliths is quite rare and poorly investigated [115,116]. According to an experimental study [117], formation of olivine with coesite, K-feldspar and phlogopite can be maintained by increasing the activity of alkalis $(\mathrm{K}$ and $\mathrm{Na}$ ) during metasomatism. High concentrations of $\mathrm{K}, \mathrm{Na}$ and $\mathrm{Cl}$ in primitive kimberlite melts $[55,56]$ provide stability of olivine with coesite, which is precluded under typical mantle conditions where alkali concentrations are low [117]. Unlike most other kimberlites worldwide, some varieties of Udachnaya-East kimberlite remain unaffected by synand postmagmatic alteration. It contains alkali carbonates, sulfates and chlorides in the groundmass (up to $8 \mathrm{wt} \% \mathrm{Na}_{2} \mathrm{O}+\mathrm{K}_{2} \mathrm{O}$ and $6 \mathrm{wt} \% \mathrm{Cl}$ ) and is almost anhydrous $\left(<0.5 \mathrm{wt} \% \mathrm{H}_{2} \mathrm{O}\right)$ [80]. In the eclogite under investigation from non-serpentinized ultra-fresh kimberlite from the Udachnaya-East body, the olivine is never in direct contact with coesite but forms part of a secondary assemblage that is restricted to the intergranular space. In this scenario, the relatively forsterite-poor olivine (Fo 83 in core) precipitated along with orthopyroxene and phlogopite from a melt that originated as derivative from a primary (proto-)kimberlite melt (precursor to the host kimberlite) but was hybridized through interaction with eclogite causing the melt to become more Fe-rich. Indeed, zoned olivines with $\mathrm{Fo}_{88}$ in the core and thin high-Fe rims have been found in carbonate-silicate polymineralic inclusions in a clinopyroxene megacryst from Diavik A154N kimberlite pipe (see Figure S2 in [59]). These inclusions were interpreted as a recrystallization product of a hybrid melt formed by a reaction between clinopyroxene, causing its partial dissolution and a percolated kimberlite melt rich in alkalis and carbon dioxide [59]. Although the evidence for partial melt loss from eclogite in this study is ambiguous, as discussed above, LREE-depletion is permissive of small degrees of partial melting of the primary assemblage which may have contributed to the hybridized melt.

The reactions of olivine formation and replacement of primary mineral assemblages in eclogite can be summarized as follows [117]:

$$
\begin{gathered}
\text { Coe }+2 / 9 \mathrm{~K}_{2} \mathrm{O}+2 / 9 \mathrm{Prp}=4 / 9 \mathrm{Kfs}+1 / 3 \mathrm{Fo} \\
\mathrm{Coe}+1 / 6 \mathrm{~K}_{2} \mathrm{O}+1 / 12 \operatorname{Prp}+1 / 12 \mathrm{Grs}=1 / 3 \mathrm{Kfs}+1 / 4 \mathrm{Di} .
\end{gathered}
$$

Secondary orthopyroxene is of quite rare occurrence in mantle eclogites [74]. Its formation is due to interaction of garnet with K-rich fluids:

$$
\text { Grt }+ \text { K-Fluid }=\text { CpxII }+ \text { Sp }+ \text { K-glass } \pm \text { Opx } \pm \text { Amp } \pm \text { Phl }
$$

Olivine grains were observed in secondary mineral assemblages, which include sodalite, spinel, plagioclase, djerfisherite, K-feldspar and CpxII. The reconstructed bulk composition of the Uv-537 eclogite does not have such high contents of $\mathrm{Na}_{2} \mathrm{O}, \mathrm{K}_{2} \mathrm{O}$ and $\mathrm{Cl}$. These elements are typical of primitive melt from the Udachnaya pipe [55,56]. Djerfisherite rims around sulfide grains result from reactions with the $\mathrm{K}$ - and $\mathrm{Cl}$ - bearing fluid [45]. Experimental studies of djerfisherite stability show the crustal origin of this mineral $[118,119]$ which thus formed late during the interaction of the kimberlite 
melt with the primary eclogitic mineral assemblages. Sodalite is a high-temperature low-pressure $(\leq 0.8 \mathrm{GPa}$ [120]) phase stable above the solidus in sodic silica-undersaturated magmas enriched in $\mathrm{NaCl}$. Thus olivine-sodalite intergrowths can form at pressures below $0.8 \mathrm{GPa}$. Aegirine $\left(\mathrm{NaFe}^{3+} \mathrm{Si}_{2} \mathrm{O}_{6}\right)$ crystals occurring in the same secondary mineral assemblage indicate a very high activity of oxygen.

According to Misra et al. [45], symplectite forms by partial melting of omphacite and garnet with involvement of $\mathrm{K}-\mathrm{Cl}-\mathrm{H}_{2} \mathrm{O}-\mathrm{CO}_{2}$-fluids, by the reaction

$$
\text { Grt }+ \text { Omp }+ \text { Fluid } / \text { melt }=\text { Amp }+ \text { CpxII + Sdl }+ \text { Cal }
$$

Garnet is commonly less strongly altered than omphacite because of their different reactivity with respect to alkaline fluids [74]. Nevertheless, in this study, omphacite appears to be homogeneous whereas garnet features compositionally distinct rims, which are discussed in the next section.

\subsubsection{Formation of Heterogeneous Garnet}

Zoned garnets are very rare in eclogitic mantle xenoliths and are rarely reported in the literature [121], unlike those from peridotitic xenoliths [122,123]. Prominent zoning in eclogitic garnets from new locations in Angola with different major-oxide contents in the core and the rim (11.2 vs. $10 \mathrm{wt} \% \mathrm{CaO}, 0.06$ vs. $0.32 \mathrm{wt} \% \mathrm{TiO}_{2} ; 11.20$ vs. $15.4 \mathrm{wt} \% \mathrm{MgO}$; and 15.2 vs. $10 \mathrm{wt} \% \mathrm{FeO}$, respectively) was most likely produced by entrainment in kimberlite and rapid upward transport [121]. Metasomatized zoned harzburgite garnets from the Wesselton kimberlite (South Africa) provide a good example of inhomogeneous garnets formed in subcontinental lithospheric mantle [123]. Sinuous REE patterns of cores in these garnets result from reactions of a strongly depleted protolith with LREE-rich and HFSE-depleted fluids, such as carbonatite. The zoning in these garnets is from low-Ca harzburgitic cores to rims with lherzolitic Ca-Cr relations. Increase in $\mathrm{Ca}$ and decrease in $\mathrm{Cr}$ and $\mathrm{Mg}$ is accompanied by increases in Zr, Y, Ti and HREE. Proceeding from these results, Griffin et al. [123,124] attributed the zoning in garnets to infiltration of a fluid/melt into the rock shortly before intrusion of the kimberlite melt. Infiltration of a melt with a high $\mathrm{Zr} / \mathrm{Y}$ ratio is additionally confirmed by $\mathrm{Zr} / \mathrm{Y}$ variations: 1 to 2 in the core vs. 4 to 5 in the rim of garnet grains [124].

The distinct zoning in eclogitic garnets from Uv-537 is manifested as a core-rim difference in major-and trace-element contents. They are, namely, 6.5 and $5 \mathrm{wt} \% \mathrm{CaO} ; 0.7$ and $0.3 \mathrm{wt} \% \mathrm{TiO}_{2} ; 13$ and $18.8 \mathrm{wt} \% \mathrm{MgO} ; 16$ and $12.6 \mathrm{wt} \% \mathrm{FeO} ; 0.25$ and $0.1 \mathrm{wt} \% \mathrm{Na}_{2} \mathrm{O} ; 2.4$ and 8 ppm $\mathrm{Zr}, 34$ and 19 ppm Y; 3.9 and 1 ppm Sr; below detection and 0.2 ppm Hf, in core and rim, respectively. Moreover, the MREE contents but not LREE contents, in the rims are lower than in the cores, which therefore probably does not reflect partial melting but the nature of the metasomatizing melt. The $\mathrm{Zr} / \mathrm{Y}$ ratio in the rim is 6.6 times that in the core. Previously [62], zoning was reported also for garnets in sheared peridotite xenoliths from the Udachnaya-East kimberlite: $\mathrm{Zr} / \mathrm{Y}=2.5$ in the core and 8.4 in the rim.

Generally, garnets from mantle-derived rocks cannot remain zoned for extended periods of time at the mantle P-T conditions (equilibrium) corresponding to their origin. It was estimated that zonation in garnets from peridotitic xenoliths persisted from 10 to $10^{4}$ years $\left(T=1200-1400{ }^{\circ} \mathrm{C}\right)$ [125] or from 25 days to 400 years $\left(T=1025 \pm 25^{\circ} \mathrm{C}, 4.2 \pm 0.5 \mathrm{GPa}\right)$ [126]. As inferred by Griffin et al. [125], metasomatism may be genetically connected to the kimberlite eruptive events or their immediate precursors. According to Jollands et al. [126], single-stage ascent of a kimberlite magma to the surface may take hours to days, and the metasomatic event may mark a precursory failed kimberlite eruption. A similar scenario was suggested [121] for eclogitic xenoliths but with coupled metasomatism and heating during entrainment and/or transport in the host kimberlite. The bulk of the metasomatic alteration of two diamondiferous eclogite xenoliths from the Udachnaya pipe [45], which consist of spongy-textured clinopyroxene, sodalite, calcite, K-feldspar, djerfisherite and a small amount of $\mathrm{K}-\mathrm{Ca}-\mathrm{Fe}-\mathrm{Mg}$ glass, was ascribed to a second metasomatic event that occurred also in the upper mantle but after the xenoliths had been incorporated into the kimberlite. 
In light of the results in this and prior studies, we suggest that primitive kimberlite melts percolated through the mantle shortly before the formation of the Udachnaya pipe. Their prolonged interaction with eclogite bodies forming part of the regional mantle lithosphere led to hybridization and is responsible for crystallization of the unusual secondary mineral assemblage in Uv-537 as well as for the formation of compositionally distinct, $\mathrm{Mg}$-richer garnet rims. A regression through the data for experiments containing both garnet and olivine in Reference [127] suggests that the garnet rim with an $\mathrm{Mg \#}$ of 0.73 would be in equilibrium with olivine with an $\mathrm{Mg \#}$ of 0.79 , which is closer to the measured olivine core than the rim composition. This suggests that the metasomatic melt continued to evolve through local reaction with the eclogite, which has a much lower bulk Mg\# than the ultramafic metasomatic melt, probably during ascent, leading to the precipitation of forsterite-poorer olivine rims and a low-pressure secondary mineral assemblage (djerfisherite and sodalite), as discussed above.

\subsubsection{Metasomatic Reactions of Primitive Melt with Eclogite}

There is additional chemical and isotope evidence for interaction of an alkaline kimberlite-like metasomatic melt with Uv-537 eclogite. For example, although the high $\mathrm{K}_{2} \mathrm{O}$ in omphacite and $\mathrm{Na}_{2} \mathrm{O}$ in garnet from Uv-537 undoubtedly in part reflect a pressure effect, as discussed above, these unusually high contents are suggested to additionally reflect metasomatism. This is supported by Rb-Sr isotope systematics in omphacite: the measured ${ }^{87} \mathrm{Sr} /{ }^{86} \mathrm{Sr}$ ratio (0.7036) is high, between modern Depleted Mantle and Primitive Mantle [128], yet ${ }^{87} \mathrm{Rb} /{ }^{86} \mathrm{Sr}$ is very low (0.0013). At the same time, age dating of mantle eclogites from Udachnaya using various radiogenic isotope systems indicates an Archean protolith age [129], suggesting initial ${ }^{87} \mathrm{Sr} /{ }^{86} \mathrm{Sr}<\sim 0.7015$, depending on the source [130]. At the very low ${ }^{87} \mathrm{Rb} /{ }^{86} \mathrm{Sr}$, the measured ${ }^{87} \mathrm{Sr} /{ }^{66} \mathrm{Sr}$ cannot be generated by in sit $u \mathrm{Rb}$ decay in the eclogite as ${ }^{87} \mathrm{Sr} /{ }^{86} \mathrm{Sr}$ increases by only 0.00006 over $2.9 \mathrm{Ga}$ (Table S2) but is strikingly similar to the lower range of ${ }^{87} \mathrm{Sr} /{ }^{86} \mathrm{Sr}$ determined for the Udachnaya kimberlite (0.7034-0.7051; [131]). It therefore seems possible that the eclogite either experienced Sr addition from or isotopically equilibrated with, an ultramafic melt similar to the host kimberlite.

As indicated above, the Udachnaya primary kimberlite melt and/or kimberlite magma had a low- $\mathrm{H}_{2} \mathrm{O}$ and $\mathrm{Cl}$-rich alkali-carbonatitic composition with high bulk $\mathrm{Zr} / \mathrm{Y}$ of 6-9 early during its ascent [55]. Moreover, some exceptionally well-preserved varieties of non-serpentinized kimberlite are likewise poor in water but rich in $\mathrm{Cl}, \mathrm{S}$ and alkalis, in the bulk composition as well as within melt inclusions in rock-forming minerals $[54,59,79,80,132-134]$. As is true in other cratons, such as the Kaapvaal $[123,126]$ and Slave [63], primary kimberlite melt from the source region apparently percolated through the mantle before the formation of the Udachnaya kimberlite. Such melt infiltration could cause partial melting of the mantle material (in particular eclogite with low solidus temperature), crystallization of mineral rims and formation of new phases. The duration and length scale of activity of precursors to successful kimberlite eruption (so-called 'failed kimberlite melts') remain unclear. For instance, microinclusions in diamond from eclogitic xenoliths in the Udachnaya kimberlite that originated at a depth of $160 \mathrm{~km}$ [34] have very high contents of alkalis and chlorine, notable amounts of sulfur and low silica, magnesium and water (molar ratio $\mathrm{H}_{2} \mathrm{O} /\left(\mathrm{H}_{2} \mathrm{O}+\mathrm{CO}_{2}\right)=0.1$ ), at high bulk $\mathrm{Zr} / \mathrm{Y}$ of 8. In general, their compositions fall in the middle of the range between low-Mg carbonatitic and saline endmember compositions of microinclusions in fibrous diamonds worldwide. Diamond-forming metasomatism was inferred [34] to shortly precede kimberlite eruption, and the microinclusions to represent saline carbonated fluids circulating at the base of the lithospheric mantle (150-170 km depth). The low amounts of water may support a genetic linkage between the microinclusions in diamonds and the host kimberlites [34]. Note that the derivates of the primary kimberlite melt at the Udachnaya site retained their main chemical features even upon prolonged infiltration and remained rich in alkalis, chlorine and $\mathrm{CO}_{2}$ but poor in silica, magnesium and water. Moreover, studies of primary crystallized multiphase melt inclusions hosted by large metasomatic ilmenite grains in a polymict mantle xenolith from the Bultfontein kimberlite (Kimberley, South Africa) [53] allowed an inference that such melts can percolate through mantle over long distances. Guliani et al. [53] presented the first 
direct evidence for the existence of alkali-carbonate melts in shallow lithospheric mantle ( 110-115 $\mathrm{km}$ ), above the diamond stability field. From textural and chemical observations, they inferred that the alkali-carbonate melt was derived from primary or precursor kimberlite magmas [53].

At Udachnaya, in any of the presented scenarios, be it infiltration of derivates from the primary kimberlite melt through eclogitic rocks in situ or interaction of the entrained eclogite with the ascending kimberlite magma, the liquid was apparently rich in alkalis and chlorine but poor in $\mathrm{H}_{2} \mathrm{O}$, as applies to the primitive kimberlite melt [55] and microinclusions in young diamonds [34]. The presence of sodalite $\left(\mathrm{Na}_{8} \mathrm{Al}_{6} \mathrm{Si}_{6} \mathrm{O}_{24} \mathrm{Cl}_{2}\right)$, K-feldspar $\left((\mathrm{K}, \mathrm{Na}, \mathrm{Ca})\left(\mathrm{Al}_{2} \mathrm{Si}_{2}\right.\right.$ or $\left.\left.\mathrm{AlSi}_{3}\right) \mathrm{O}_{8}\right)$, mica $\left(\mathrm{K}(\mathrm{Mg}, \mathrm{Fe})_{3}\left[\mathrm{Si}_{3} \mathrm{AlO}_{10}\right][\mathrm{OH}, \mathrm{F}]_{2}\right)$ and djerfisherite $\left(\mathrm{K}_{6}(\mathrm{Fe}, \mathrm{Ni}, \mathrm{Cu})_{25} \mathrm{~S}_{26} \mathrm{Cl}\right)$ among interstitial phases indicates alkali and $\mathrm{Cl}$ enrichment of the liquid that interacted with the eclogite. Note that the presence of minor amounts of mica $(<1 \mathrm{vol} \%$ of the interstitial space) does not mean, by itself, that the melt would be hydrous and $<<1 \mathrm{wt} \% \mathrm{H}_{2} \mathrm{O}$ are inferred. The preservation of coesite in the Uv-537 sample indicates quite low concentration of water in the system 'eclogite-metasomatizing melt' because, as shown previously [135], coesite-to-quartz conversion is catalyzed by interaction with hydrous melts/fluids.

In summary, based on petrographic and mineral compositional evidence, we envisage the following sequence of metasomatic events, summarized in Figure 9: (I) ancient metasomatic event by alkaline fluid/melt resulted in high contents of $\mathrm{K}_{2} \mathrm{O}$ in omphacitic clinopyroxene and $\mathrm{Na}_{2} \mathrm{O}$ in garnet. (II) Formation of $\mathrm{Mg}$-rich rims in garnet and $\mathrm{Mg}$-rich cores in olivine results from reaction of alkali-rich kimberlite-related melt with eclogite rock residing in the mantle lithosphere beneath Udachnaya just prior to kimberlite eruption. (III) Formation of Fe-rich olivine rims, orthopyroxene (?), phlogopite, sodalite, djerfisherite, garnet kelyphitic rims and symplectite after primary omphacite may have resulted from an interaction with residual hybrid melt formed at stage II or/and transporting kimberlite melt during uplift of the eclogites.

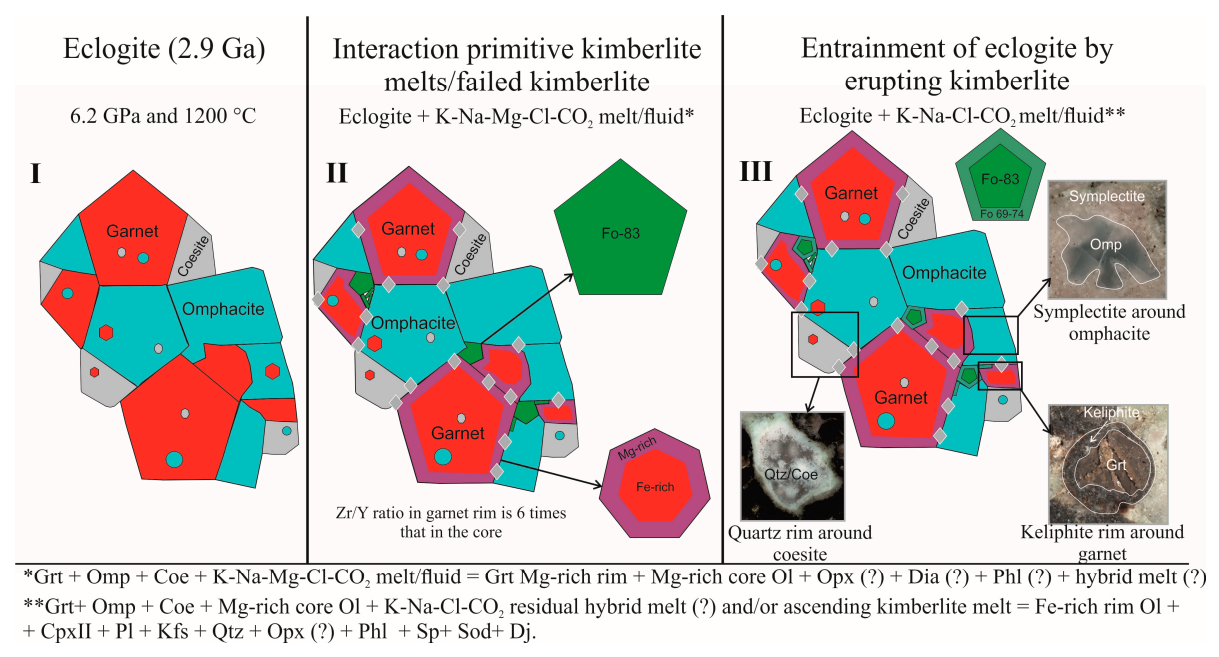

Figure 9. Cartoon illustrating the pre-kimberlite magmatism history of xenolith Uv-537 and processes involved in its multi-stage evolution (note that depicted mineral volumes are approximate and not designed to represent fluxes). I: Formation of coesite-bearing eclogite ( 2.9 Ga) and ancient metasomatic event; II: interaction of eclogite with a metasomatizing carbonatitic or alkali carbonatitic melt (precursory of kimberlite magmatism) produces Mg-rich cores in olivine (Ol, Fo-forsterite number) and Mg-rich rims on garnet (Grt). Omp-omphacite; Coe-coesite; Opx-orthopyroxene; Dia—diamond; Phl—phlogopite; III: transport of eclogite to the surface by kimberlite melt leading to growth of Fe-rich olivine rims, formation of quartz (Qtz) rim around coesite, symplectite after primary omphacite (CpxII—secondary clinopyroxene, Pl—plagioclase, Kfs-K-feldspar), orthopyroxene (?), phlogopite, spinel (Sp), sodalite (Sod), djerfisherite (Dj) and garnet kelyphitic rims. 


\section{Summary and Conclusions}

The reported assemblage of garnet, omphacitic clinopyroxene and olivine in a diamond- and coesite-bearing eclogitic xenolith sample from the Udachnaya kimberlite allow to place constraints on the formation of a mixed eclogitic-peridotitic mineral paragenesis (Figure 9) known previously only from inclusions in diamond. The mixed paragenesis could be formed by interaction between eclogite and a kimberlite-related melt.

The main conclusions can be summarized as follows:

1. The reconstructed bulk composition of the diamond-coesite eclogite sample Uv-537 indicates its origin from common oceanic protoliths such as mafic gabbroic cumulates which typically form part of the lower crust in mid-ocean ridges. The unusually high contents of $\mathrm{K}_{2} \mathrm{O}$ in omphacitic clinopyroxene and $\mathrm{Na}_{2} \mathrm{O}$ in garnet most likely result as a combination of subsequent transport to high pressures ( $\geq 6 \mathrm{GPa}$ ) and metasomatism of eclogite by an alkaline fluid/melt.

2. Omphacite from the Uv-537 eclogite has a high measured ${ }^{87} \mathrm{Sr} /{ }^{86} \mathrm{Sr}$ ratio $(0.7036)$ that cannot be produced from the in situ decay of the low amount of $\mathrm{Rb}$ present $\left({ }^{87} \mathrm{Rb} /{ }^{86} \mathrm{Sr}\right.$ of 0.0013$)$ even for an assumed protolith age of $2.9 \mathrm{Ga}$. The ${ }^{87} \mathrm{Sr} /{ }^{86} \mathrm{Sr}$ is, however, similar to the lower end of ${ }^{87} \mathrm{Sr} /{ }^{86} \mathrm{Sr}$ determined for the host kimberlite and therefore suggested to reflect isotopic equilibration with, or Sr addition from, a melt with kimberlite affinity.

3. Zoning in garnet is ascribed to reaction with a percolated and hybridized kimberlite melt shortly before eruption. The $\mathrm{Zr} / \mathrm{Y}$ ratio (6 times greater in the rim than in the core of garnet grains) records precipitation of the garnet rim from a kimberlite-related melt having high $\mathrm{Zr} / \mathrm{Y}$. As mineral zoning cannot persist for extended timescales at upper mantle temperatures, it must reflect processes immediately preceding kimberlite eruption.

4. The secondary mineral assemblage is formed by reaction of eclogite with derivates of the primary kimberlite melt. Formation of Mg-rich rims in garnet and Mg-rich cores in olivine results from reaction of alkali-rich kimberlite-related melt with eclogite rock residing in the mantle lithosphere beneath Udachnaya. Fe-rich olivine rims, quartz rim around coesite, symplectite after primary omphacite (secondary clinopyroxene, plagioclase, K-feldspar), djerfisherite, sodalite, possibly orthopyroxene and garnet kelyphitic rims were produced by the latest metasomatic reactions during eclogite transport by the kimberlite melt.

5. The preservation of coesite, along with very fast ascent of the kimberlite melt, supports very low $\mathrm{H}_{2} \mathrm{O}$ contents in the latter. The water-poor kimberlite melt composition is confirmed by the lack of serpentine in the groundmass of a fresh kimberlite sample from the Udachnaya-East pipe $[79,80,132,134]$.

Supplementary Materials: The following supplementary materials are available online at http://www.mdpi. com/2075-163X/10/4/383/s1: Figure S1: Single-element maps of Si, Ti, Al, Cr, Fe, Mn, Mg, Ca, Na and K in orthopyroxene from Uv-537 eclogite; Figure S2: BSE images and single-element maps of $\mathrm{Si}, \mathrm{Al}, \mathrm{Fe}, \mathrm{Mn}$ and $\mathrm{Mg}$ in olivine from Uv-537 eclogite; Table S1: Major-element composition ( $w \mathrm{t} \%$ ) of primary rock-forming (garnet and omphacite) and accessory minerals in Uv-537 eclogite; Table S2: Trace-element composition (ppm) of garnet (grt) and clinopyroxene (cpx) in Uv-537 eclogite; Table S3: Bulk rock composition of Uv-537 eclogite (major oxides in $\mathrm{wt} \%$, trace elements in $\mathrm{ppm}$ ).

Author Contributions: conceptualization, D.M., A.G. (Alexander Golovin) and A.K.; methodology, S.A., A.G. (Axel Gerdes); software, D.M.; validation, S.A., A.K. and A.R.; formal analysis, S.A., A.R., A.G. (Axel Gerdes) and D.M.; investigation, D.M. and A.K.; data curation, D.M.; writing-original draft preparation, D.M., A.G. (Alexander Golovin) and A.K.; writing — review and editing, S.A., A.K. and A.G. (Alexander Golovin); visualization, D.M. All authors have read and agreed to the published version of the manuscript.

Funding: The study was supported by the Russian Science Foundation (Project 18-77-00041). Raman measurements were performed with support by the state assignment of IGM SB RAS. The Deutsche Forschungsgemeinschaft is gratefully acknowledged for funding to SA (DFG-grant AU356/10). FIERCE is financially supported by the Wilhelm and Else Heraeus Foundation and by the Deutsche Forschungsgemeinschaft (DFG, INST 161/921-1 FUGG and INST 161/923-1 FUGG), which is gratefully acknowledged. This is FIERCE contribution No. 16. 
Acknowledgments: D.M. acknowledges the Chinese Academy of Sciences President's International Fellowship Initiative (PIFI) for Postdoctoral Researchers (grant 2019PC0033) and thanks A. Shatskiy and T. Alifirova for discussions. Thanks are extended to D. Rezvukhin for assistance in draft manuscript preparation and discussions, as well as to E. Nigmatulina and M. Khlestov for analytical work (EMPA).

Conflicts of Interest: The authors declare no conflict of interest.

\section{References}

1. Snyder, G.A.; Taylor, L.A.; Jerde, E.A.; Clayton, R.N.; Mayeda, T.K.; Deines, P.; Rossman, G.R.; Sobolev, N.V. Archean mantle heterogeneity and the origin of diamondiferous eclogites, Siberia: Evidence from stable isotopes and hydroxyl in garnet. Am. Mineral. 1995, 80, 799-809. [CrossRef]

2. Jacob, D.E. Nature and origin of eclogite xenoliths from kimberlites. Lithos 2004, 77, 295-316. [CrossRef]

3. Aulbach, S.; Jacob, D.E. Major- and trace-elements in cratonic mantle eclogites and pyroxenites reveal heterogeneous sources and metamorphic processing of low-pressure protoliths. Lithos 2016, 262, $586-605$. [CrossRef]

4. Griffin, W.L.; O’Reilly, S.Y. Cratonic lithospheric mantle: Is anything subducted? Episodes 2007, 30, 43-53. [CrossRef] [PubMed]

5. Hatton, C.J.; Gurney, J.J. Roberts Victor eclogites and their relation to the mantle. In Mantle Xenoliths; Nixon, P.H., Ed.; John Wiley \& Sons: New York, NY, USA, 1987; pp. 453-463.

6. Barth, M.G.; Rudnick, R.L.; Horn, I.; McDonough, W.F.; Spicuzza, M.J.; Valley, J.W.; Haggerty, S.E. Geochemistry of xenolithic eclogites from West Africa, Part I: A link between low MgO eclogites and Archean crust formation. Geochim. Cosmochim. Acta 2001, 65, 1499-1527. [CrossRef]

7. Taylor, L.A.; Anand, M. Diamonds: Time capsules from the Siberian Mantle. Chem. Der Erde-Geochem. 2004, 64, 1-74. [CrossRef]

8. Liu, Y.; Taylor, L.A.; Sarbadhikari, A.B.; Valley, J.W.; Ushikubo, T.; Spicuzza, M.J.; Kita, N.; Ketcham, R.A.; Carlson, W.; Shatsky, V. Metasomatic origin of diamonds in the world's largest diamondiferous eclogite. Lithos 2009, 112, 1014-1024. [CrossRef]

9. Stachel, T.; Harris, J. The origin of cratonic diamonds-Constraints from mineral inclusions. Ore Geol. Rev. 2008, 34, 5-32. [CrossRef]

10. Stepanov, A.; Shatsky, V.; Zedgenizov, D.; Sobolev, N. Causes of variations in morphology and impurities of diamonds from the Udachnaya Pipe eclogite. Russ. Geol. Geophys. 2007, 48, 758-769. [CrossRef]

11. Stachel, T.; Luth, R.W. Diamond formation-Where, when and how? Lithos 2015, 220, 200-220. [CrossRef]

12. Sobolev, N.V. Deep-Seated Inclusions in Kimberlites and the Problem of the Composition of the Upper Mantle; Amer Geophysical Union: Washington, DC, USA, 1977.

13. Meyer, H. Mantle Xenoliths; Wiley: Chichester, UK, 1987.

14. Sobolev, N.; Taylor, L.; Zuev, V.; Bezborodov, S.; Snyder, G.; Sobolev, V.; Yefimova, E. The specific features of eclogitic paragenesis of diamonds from Mir and Udachnaya kimberlite pipes (Yakutia). Russ. Geol. Geophys. 1998, 39, 1667-1678.

15. Schulze, D.J.; Valley, J.W.; Spicuzza, M.J. Coesite eclogites from the Roberts Victor kimberlite, South Africa. Lithos 2000, 54, 23-32. [CrossRef]

16. Sobolev, N.V.; Logvinova, A.M.; Zedgenizov, D.A.; Pokhilenko, N.P.; Malygina, E.V.; Kuzmin, D.V.; Sobolev, A.V. Petrogenetic significance of minor elements in olivines from diamonds and peridotite xenoliths from kimberlites of Yakutia. Lithos 2009, 112, 701-713. [CrossRef]

17. Prinz, M.; Mansoni, D.V.; Hlava, P.F.; Keil, K. Inclusions in diamonds: Garnet lherzolite and eclogite assemblages. In Physics and Chemistry of the Earth; Elsevier: Amsterdam, The Netherlands, 1975; pp. 797-815.

18. Hall, A.; Smith, C.B. Lamproite diamonds-are they different. Kimberl. Occur. Orig. A Basis Concept. Models Explor. 1984, 8, 167-212.

19. Moore, R.O.; Gurney, J.J. Mineral inclusions in diamonds from the Monastery kimberlite, South Africa. In Proceedings of the International Kimberlite Conference: Extended Abstracts, Perth, Australia, 11-15 August 1986; pp. 1406-1408.

20. Otter, M.L.; Gurney, J.J. Mineral inclusions in diamonds from the Sloan diatremes, Colorado-Wyoming State Line kimberlite district, North America. Kimberl. Relat. Rocks 1989, 2, 1042-1053.

21. Bulanova, G.P. The formation of diamond. J. Geochem. Explor. 1995, 53, 1-23. [CrossRef] 
22. Stachel, T.; Harris, J.W.; Brey, G.P. Rare and unusual mineral inclusions in diamonds from Mwadui, Tanzania. Contrib. Mineral. Petrol. 1998, 132, 34-47. [CrossRef]

23. Wang, W. Formation of diamond with mineral inclusions of "mixed" eclogite and peridotite paragenesis. Earth Planet. Sci. Lett. 1998, 160, 831-843. [CrossRef]

24. Ragozin, A.L.; Shatsky, V.S.; Zedgenizov, D.A.; Mityukhin, S.I. Evidence for evolution of diamond crystallization medium in eclogite xenolith from the Udachnaya kimberlite pipe, Yakutia. Dokl. Earth Sci. 2006, 407, 465-468. [CrossRef]

25. Gubanov, N.; Zedgenizov, D.; Sharygin, I.; Ragozin, A. Origin and Evolution of High-Mg Carbonatitic and Low-Mg Carbonatitic to Silicic High-Density Fluids in Coated Diamonds from Udachnaya Kimberlite Pipe. Minerals 2019, 9, 734. [CrossRef]

26. Yaxley, G.M.; Green, D.H.; Kamenetsky, V. Carbonatite metasomatism in the southeastern Australian lithosphere. J. Petrol. 1998, 39, 1917-1930. [CrossRef]

27. Izraeli, E.S.; Harris, J.W.; Navon, O. Brine inclusions in diamonds: A new upper mantle fluid. Earth Planet. Sci. Lett. 2001, 187, 323-332. [CrossRef]

28. Klein-BenDavid, O.; Izraeli, E.S.; Hauri, E.; Navon, O. Mantle fluid evolution-A tale of one diamond. Lithos 2004, 77, 243-253. [CrossRef]

29. Klein-BenDavid, O.; Izraeli, E.S.; Hauri, E.; Navon, O. Fluid inclusions in diamonds from the Diavik mine, Canada and the evolution of diamond-forming fluids. Geochim. Cosmochim. Acta 2007, 71, 723-744. [CrossRef]

30. Klein-BenDavid, O.; Logvinova, A.M.; Schrauder, M.; Spetius, Z.V.; Weiss, Y.; Hauri, E.H.; Kaminsky, F.V.; Sobolev, N.V.; Navon, O. High-Mg carbonatitic microinclusions in some Yakutian diamonds-A new type of diamond-forming fluid. Lithos 2009, 112, 648-659. [CrossRef]

31. Weiss, Y.; Kessel, R.; Griffin, W.; Kiflawi, I.; Klein-BenDavid, O.; Bell, D.; Harris, J.; Navon, O. A new model for the evolution of diamond-forming fluids: Evidence from microinclusion-bearing diamonds from Kankan, Guinea. Lithos 2009, 112, 660-674. [CrossRef]

32. Zedgenizov, D.; Rege, S.; Griffin, W.; Kagi, H.; Shatsky, V. Composition of trapped fluids in cuboid fibrous diamonds from the Udachnaya kimberlite: LA-ICP-MS analysis. Chem. Geol. 2007, 240, 151-162. [CrossRef]

33. Zedgenizov, D.; Ragozin, A.; Shatsky, V.; Araujo, D.; Griffin, W.L.; Kagi, H. Mg and Fe-rich carbonate-Silicate high-density fluids in cuboid diamonds from the Internationalnaya kimberlite pipe (Yakutia). Lithos 2009, 112, 638-647. [CrossRef]

34. Zedgenizov, D.; Ragozin, A.; Shatsky, V.; Griffin, W. Diamond formation during metasomatism of mantle eclogite by chloride-carbonate melt. Contrib. Mineral. Petrol. 2018, 173, 84. [CrossRef]

35. Sobolev, N.; Kaminsky, F.; Griffin, W.; Yefimova, E.; Win, T.; Ryan, C.; Botkunov, A. Mineral inclusions in diamonds from the Sputnik kimberlite pipe, Yakutia. Lithos 1997, 39, 135-157. [CrossRef]

36. Leost, I.; Stachel, T.; Brey, G.; Harris, J.; Ryabchikov, I. Diamond formation and source carbonation: Mineral associations in diamonds from Namibia. Contrib. Mineral. Petrol. 2003, 145, 15-24. [CrossRef]

37. Kaminsky, F.; Wirth, R.; Matsyuk, S.; Schreiber, A.; Thomas, R. Nyerereite and nahcolite inclusions in diamond: Evidence for lower-mantle carbonatitic magmas. Mineral. Mag. 2009, 73, 797-816. [CrossRef]

38. Kaminsky, F. Mineralogy of the lower mantle: A review of 'super-deep'mineral inclusions in diamond. Earth-Sci. Rev. 2012, 110, 127-147. [CrossRef]

39. Kaminsky, F.V.; Wirth, R.; Schreiber, A. A microinclusion of lower-mantle rock and other mineral and nitrogen lower-mantle inclusions in a diamond. Can. Mineral. 2015, 53, 83-104. [CrossRef]

40. Logvinova, A.; Wirth, R.; Zedgenizov, D.; Taylor, L. Carbonate-Silicate-Sulfide Polyphase Inclusion in Diamond from the Komsomolskaya Kimberlite Pipe, Yakutia. Geochem. Int. 2018, 56, 283-291. [CrossRef]

41. Ionov, D.A.; Dupuy, C.; O’Reilly, S.Y.; Kopylova, M.G.; Genshaft, Y.S. Carbonated peridotite xenoliths from Spitsbergen: Implications for trace element signature of mantle carbonate metasomatism. Earth Planet. Sci. Lett. 1993, 119, 283-297. [CrossRef]

42. Kogarko, L.; Henderson, C.; Pacheco, H. Primary Ca-rich carbonatite magma and carbonate-silicate-sulphide liquid immiscibility in the upper mantle. Contrib. Mineral. Petrol. 1995, 121, 267-274. [CrossRef]

43. Yaxley, G.M.; Kamenetsky, V.; Green, D.H.; Falloon, T.J. Glasses in mantle xenoliths from western Victoria, Australia and their relevance to mantle processes. Earth Planet. Sci. Lett. 1997, 148, 433-446. [CrossRef]

44. Laurora, A.; Mazzucchelli, M.; Rivalenti, G.; Vannucci, R.; Zanetti, A.; Barbieri, M.A.; Cingolani, C.A. Metasomatism and melting in carbonated peridotite xenoliths from the mantle wedge: The Gobernador Gregores case (Southern Patagonia). J. Petrol. 2001, 42, 69-87. [CrossRef] 
45. Misra, K.C.; Anand, M.; Taylor, L.A.; Sobolev, N.V. Multi-stage metasomatism of diamondiferous eclogite xenoliths from the Udachnaya kimberlite pipe, Yakutia, Siberia. Contrib. Mineral. Petrol. 2004, 146, 696-714. [CrossRef]

46. Moine, B.; Grégoire, M.; O’Reilly, S.Y.; Delpech, G.; Sheppard, S.; Lorand, J.; Renac, C.; Giret, A.; Cottin, J. Carbonatite melt in oceanic upper mantle beneath the Kerguelen Archipelago. Lithos 2004, 75, $239-252$. [CrossRef]

47. Ionov, D.A.; Doucet, L.S.; Xu, Y.; Golovin, A.V.; Oleinikov, O.B. Reworking of Archean mantle in the NE Siberian craton by carbonatite and silicate melt metasomatism: Evidence from a carbonate-bearing, dunite-to-websterite xenolith suite from the Obnazhennaya kimberlite. Geochim. Cosmochim. Acta 2018, 224, 132-153. [CrossRef]

48. Ionov, D.A.; Qi, Y.-H.; Kang, J.-T.; Golovin, A.V.; Oleinikov, O.B.; Zheng, W.; Anbar, A.D.; Zhang, Z.-F.; Huang, F. Calcium isotopic signatures of carbonatite and silicate metasomatism, melt percolation and crustal recycling in the lithospheric mantle. Geochim. Cosmochim. Acta 2019, 248, 1-13. [CrossRef]

49. McGetchin, T.R.; Besancon, J. Carbonate inclusions in mantle-derived pyropes. Earth Planet. Sci. Lett. 1973, 18, 408-410. [CrossRef]

50. Smith, D. Genesis of carbonate in pyrope from ultramafic diatremes on the Colorado Plateau, southwestern United States. Contrib. Mineral. Petrol. 1987, 97, 389-396. [CrossRef]

51. Rezvukhin, D.I.; Malkovets, V.G.; Sharygin, I.S.; Tretiakova, I.G.; Griffin, W.L.; O'Reilly, S.Y. Inclusions of crichtonite-group minerals in Cr-pyropes from the Internatsionalnaya kimberlite pipe, Siberian Craton: Crystal chemistry, parageneses and relationships to mantle metasomatism. Lithos 2018, 308, 181-195. [CrossRef]

52. Araújo, D.; Griffin, W.L.; O’Reilly, S.Y. Mantle melts, metasomatism and diamond formation: Insights from melt inclusions in xenoliths from Diavik, Slave Craton. Lithos 2009, 112, 675-682. [CrossRef]

53. Giuliani, A.; Kamenetsky, V.S.; Phillips, D.; Kendrick, M.; Wyatt, B.; Goemann, K. Nature of alkali-carbonate fluids in the sub-continental lithospheric mantle. Geology 2012, 40, 967-970. [CrossRef]

54. Golovin, A.V.; Sharygin, I.S.; Korsakov, A.V. Origin of alkaline carbonates in kimberlites of the Siberian craton: Evidence from melt inclusions in mantle olivine of the Udachnaya-East pipe. Chem. Geol. 2017, 455, 357-375. [CrossRef]

55. Golovin, A.V.; Sharygin, I.S.; Kamenetsky, V.S.; Korsakov, A.V.; Yaxley, G.M. Alkali-carbonate melts from the base of cratonic lithospheric mantle: Links to kimberlites. Chem. Geol. 2018, 483, 261-274. [CrossRef]

56. Golovin, A.; Sharygin, I.; Korsakov, A.; Kamenetsky, V.; Abersteiner, A. Can primitive kimberlite melts be alkali-carbonate liquids: Composition of the melt snapshots preserved in deepest mantle xenoliths. J. Raman Spectrosc. 2019, in press. [CrossRef]

57. van Achterbergh, E.; Griffin, W.L.; Ryan, C.G.; O’Reilly, S.Y.; Pearson, N.J.; Kivi, K.; Doyle, B.J. Subduction signature for quenched carbonatites from the deep lithosphere. Geology 2002, 30, 743-746. [CrossRef]

58. Bussweiler, Y.; Stone, R.S.; Pearson, D.G.; Luth, R.W.; Stachel, T.; Kjarsgaard, B.A.; Menzies, A. The evolution of calcite-bearing kimberlites by melt-rock reaction: Evidence from polymineralic inclusions within clinopyroxene and garnet megacrysts from Lac de Gras kimberlites, Canada. Contrib. Mineral. Petrol. 2016, 171, 65. [CrossRef]

59. Abersteiner, A.; Kamenetsky, V.S.; Goemann, K.; Golovin, A.V.; Sharygin, I.S.; Giuliani, A.; Rodemann, T.; Spetsius, Z.V.; Kamenetsky, M. Djerfisherite in kimberlites and their xenoliths: Implications for kimberlite melt evolution. Contrib. Mineral. Petrol. 2019, 174, 8. [CrossRef]

60. Bussweiler, Y. Polymineralic Inclusions in Megacrysts as Proxies for Kimberlite Melt Evolution-A Review. Minerals 2019, 9, 530. [CrossRef]

61. Abersteiner, A.; Kamenetsky, V.S.; Goemann, K.; Golovin, A.V.; Sharygin, I.S.; Pearson, D.G.; Kamenetsky, M.; Gornova, M.A. Polymineralic inclusions in kimberlite-hosted megacrysts: Implications for kimberlite melt evolution. Lithos 2019, 336, 310-325. [CrossRef]

62. Agashev, A.; Ionov, D.; Pokhilenko, N.; Golovin, A.; Cherepanova, Y.; Sharygin, I. Metasomatism in lithospheric mantle roots: Constraints from whole-rock and mineral chemical composition of deformed peridotite xenoliths from kimberlite pipe Udachnaya. Lithos 2013, 160, 201-215. [CrossRef]

63. Aulbach, S.; Griffin, W.L.; Pearson, N.J.; O'Reilly, S.Y. Nature and timing of metasomatism in the stratified mantle lithosphere beneath the central Slave craton (Canada). Chem. Geol. 2013, 352, 153-169. [CrossRef] 
64. Rudnick, R.L.; McDonough, W.F.; Chappell, B.W. Carbonatite metasomatism in the northern Tanzanian mantle: Petrographic and geochemical characteristics. Earth Planet. Sci. Lett. 1993, 114, 463-475. [CrossRef]

65. Shu, Q.; Brey, G.P. Ancient mantle metasomatism recorded in subcalcic garnet xenocrysts: Temporal links between mantle metasomatism, diamond growth and crustal tectonomagmatism. Earth Planet. Sci. Lett. 2015, 418, 27-39. [CrossRef]

66. Wallace, M.E.; Green, D.H. An experimental determination of primary carbonatite magma composition. Nature 1988, 335, 343. [CrossRef]

67. Dalton, J.A.; Wood, B.J. The compositions of primary carbonate melts and their evolution through wallrock reaction in the mantle. Earth Planet. Sci. Lett. 1993, 119, 511-525. [CrossRef]

68. Safonov, O.G.; Perchuk, L.L.; Litvin, Y.A. Melting relations in the chloride-carbonate-silicate systems at high-pressure and the model for formation of alkalic diamond-forming liquids in the upper mantle. Earth Planet. Sci. Lett. 2007, 253, 112-128. [CrossRef]

69. Dasgupta, R.; Hirschmann, M.M.; McDonough, W.F.; Spiegelman, M.; Withers, A.C. Trace element partitioning between garnet lherzolite and carbonatite at 6.6 and 8.6 GPa with applications to the geochemistry of the mantle and of mantle-derived melts. Chem. Geol. 2009, 262, 57-77. [CrossRef]

70. Dasgupta, R.; Mallik, A.; Tsuno, K.; Withers, A.C.; Hirth, G.; Hirschmann, M.M. Carbon-dioxide-rich silicate melt in the Earth's upper mantle. Nature 2013, 493, 211. [CrossRef]

71. Litasov, K.D.; Shatskiy, A.; Ohtani, E.; Yaxley, G.M. Solidus of alkaline carbonatite in the deep mantle. Geology 2013, 41, 79-82. [CrossRef]

72. Shatskiy, A.; Litasov, K.D.; Sharygin, I.S.; Ohtani, E. Composition of primary kimberlite melt in a garnet lherzolite mantle source: Constraints from melting phase relations in anhydrous Udachnaya-East kimberlite with variable CO2 content at $6.5 \mathrm{GPa}$. Gondwana Res. 2017, 45, 208-227. [CrossRef]

73. Jacob, D.; Jagoutz, E.; Lowry, D.; Mattey, D.; Kudrjavtseva, G. Diamondiferous eclogites from Siberia: Remnants of Archean oceanic crust. Geochim. Cosmochim. Acta 1994, 58, 5191-5207. [CrossRef]

74. Spetsius, Z.V.; Taylor, L.A. Partial Melting in Mantle Eclogite Xenoliths: Connections with Diamond Paragenesis. Int. Geol. Rev. 2002, 44, 973-987. [CrossRef]

75. Lavrent'ev, Y.G.; Karmanov, N.; Usova, L. Electron probe microanalysis of minerals: Microanalyzer or scanning electron microscope? Russ. Geol. Geophys. 2015, 56, 1154-1161. [CrossRef]

76. Aulbach, S.; Viljoen, K. Eclogite xenoliths from the Lace kimberlite, Kaapvaal craton: From convecting mantle source to palaeo-ocean floor and back. Earth Planet. Sci. Lett. 2015, 431, 274-286. [CrossRef]

77. Aulbach, S.; Gerdes, A.; Viljoen, K. Formation of diamondiferous kyanite-eclogite in a subduction mélange. Geochim. Cosmochim. Acta 2016, 179, 156-176. [CrossRef]

78. Kharkiv, A.; Zuenko, V.; Zinchuk, N.; Kryuchkov, A.; Ukhanov, V.; Bogatykh, M. Petrochemistry of kimberlites; Nedra: Moscow, Russia, 1991; 304p.

79. Kamenetsky, V.S.; Golovin, A.V.; Maas, R.; Giuliani, A.; Kamenetsky, M.B.; Weiss, Y. Towards a new model for kimberlite petrogenesis: Evidence from unaltered kimberlites and mantle minerals. Earth-Sci. Rev. 2014, 139, 145-167. [CrossRef]

80. Kamenetsky, V.S.; Kamenetsky, M.B.; Golovin, A.V.; Sharygin, V.V.; Maas, R. Ultrafresh salty kimberlite of the Udachnaya-East pipe (Yakutia, Russia): A petrological oddity or fortuitous discovery? Lithos 2012, 152, 173-186. [CrossRef]

81. Morimoto, N. Nomenclature of pyroxenes. Mineral. Petrol. 1988, 39, 55-76. [CrossRef]

82. Taylor, L.A.; Neal, C.R. Eclogites with Oceanic Crustal and Mantle Signatures from the Bellsbank Kimberlite, South Africa, Part I: Mineralogy, Petrography and Whole Rock Chemistry. J. Geol. 1989, 97, 551-567. [CrossRef]

83. Coleman, R.G.; Lee, D.E.; Beatty, L.B.; Brannock, W.W. Eclogites and eclogites: Their differences and similarities. Geol. Soc. Am. Bull. 1965, 76, 483-508. [CrossRef]

84. Nasdala, L.; Steger, S.; Reissner, C. Raman study of diamond-based abrasives and possible artefacts in detecting UHP microdiamond. Lithos 2016, 265, 317-327. [CrossRef]

85. Yaxley, G.M.; Berry, A.J.; Kamenetsky, V.S.; Woodland, A.B.; Golovin, A.V. An oxygen fugacity profile through the Siberian Craton-Fe K-edge XANES determinations of $\mathrm{Fe} 3+/ \sum \mathrm{Fe}$ in garnets in peridotite xenoliths from the Udachnaya East kimberlite. Lithos 2012, 140, 142-151. [CrossRef] 
86. Ionov, D.A.; Doucet, L.S.; von Strandmann, P.A.P.; Golovin, A.V.; Korsakov, A.V. Links between deformation, chemical enrichments and Li-isotope compositions in the lithospheric mantle of the central Siberian craton. Chem. Geol. 2017, 475, 105-121. [CrossRef]

87. Doucet, L.S.; Ionov, D.A.; Golovin, A.V. The origin of coarse garnet peridotites in cratonic lithosphere: New data on xenoliths from the Udachnaya kimberlite, central Siberia. Contrib. Mineral. Petrol. 2013, 165, 1225-1242. [CrossRef]

88. Sobolev, N.; Sobolev, A.; Tomilenko, A.; Batanova, V.; Tolstov, A.; Logvinova, A.; Kuz'min, D. Unique compositional peculiarities of olivine phenocrysts from the post flood basalt diamondiferous Malokuonapskaya kimberlite pipe, Yakutia. Dokl. Earth Sci. 2015, 463, 828. [CrossRef]

89. Sobolev, N.; Sobolev, A.; Tomilenko, A.; Kuz'min, D.; Grakhanov, S.; Batanova, V.; Logvinova, A.; Bul'bak, T.; Kostrovitskii, S.; Yakovlev, D. Prospects of search for diamondiferous kimberlites in the northeastern Siberian Platform. Russ. Geol. Geophys. 2018, 59, 1365-1379. [CrossRef]

90. Kamenetsky, V.S.; Kamenetsky, M.B.; Sobolev, A.V.; Golovin, A.V.; Demouchy, S.; Faure, K.; Sharygin, V.V.; Kuzmin, D.V. Olivine in the Udachnaya-East kimberlite (Yakutia, Russia): Types, compositions and origins. J. Petrol. 2007, 49, 823-839. [CrossRef]

91. Sobolev, N.; Sobolev, A.; Tomilenko, A.; Kovyazin, S.; Batanova, V.; Kuz'min, D. Paragenesis and complex zoning of olivine macrocrysts from unaltered kimberlite of the Udachnaya-East pipe, Yakutia: Relationship with the kimberlite formation conditions and evolution. Russ. Geol. Geophys. 2015, 56, 260-279. [CrossRef]

92. Orlov, U.L. The Mineralogy of the Diamond; John Wiley \& Sons: Hoboken, NJ, USA, 1977.

93. McDonough, W.F.; Sun, S.-S. The composition of the Earth. Chem. Geol. 1995, 120, 223-253. [CrossRef]

94. Sun, S.-S.; McDonough, W.F. Chemical and isotopic systematics of oceanic basalts: Implications for mantle composition and processes. Geol. Soc. Lond. Spec. Publ. 1989, 42, 313-345. [CrossRef]

95. Perk, N.W.; Coogan, L.A.; Karson, J.A.; Klein, E.M.; Hanna, H.D. Petrology and geochemistry of primitive lower oceanic crust from Pito Deep: Implications for the accretion of the lower crust at the Southern East Pacific Rise. Contrib. Mineral. Petrol. 2007, 154, 575-590. [CrossRef]

96. Casey, J.F. Comparison of major-and trace-element geochemistry of abyssal peridotites and mafic plutonic rocks with basalts from the MARK region of the Mid-Atlantic Ridge. Proc. Ocean Drill. Program Sci. Results 1997, 153, 181-241.

97. Safonov, O.G.; Bindi, L.; Vinograd, V.L. Potassium-bearing clinopyroxene: A review of experimental, crystal chemical and thermodynamic data with petrological applications. Mineral. Mag. 2011, 75, 2467-2484. [CrossRef]

98. Kushiro, I.; Erlank, A. Stability of potassic richterite. Carnegie Inst. Wash. Yearb. 1970, 68, 231-233.

99. Xiong, X.; Keppler, H.; Audétat, A.; Gudfinnsson, G.; Sun, W.; Song, M.; Xiao, W.; Yuan, L. Experimental constraints on rutile saturation during partial melting of metabasalt at the amphibolite to eclogite transition, with applications to TTG genesis. Am. Mineral. 2009, 94, 1175-1186. [CrossRef]

100. Klemme, S.; Prowatke, S.; Hametner, K.; Günther, D. Partitioning of trace elements between rutile and silicate melts: Implications for subduction zones. Geochim. Cosmochim. Acta 2005, 69, 2361-2371. [CrossRef]

101. Safonov, O.G.; Perchuk, L.L.; Litvin, Y.A. Equilibrium K-bearing clinopyroxene-melt as a model for barometry of mantle-derived mineral assemblages. Russ. Geol. Geophys. 2005, 46, 1318-1334.

102. Ellis, D.; Green, D. An experimental study of the effect of Ca upon garnet-clinopyroxene Fe-Mg exchange equilibria. Contrib. Mineral. Petrol. 1979, 71, 13-22. [CrossRef]

103. Beyer, C.; Frost, D.; Miyajima, N. Experimental calibration of a garnet-clinopyroxene geobarometer for mantle eclogites. Contrib. Mineral. Petrol. 2015, 169, 18. [CrossRef]

104. Pollack, H.N.; Chapman, D.S. On the regional variation of heat flow, geotherms and lithospheric thickness. Tectonophysics 1977, 38, 279-296. [CrossRef]

105. Heaman, L.M.; Creaser, R.A.; Cookenboo, H.O.; Chacko, T. Multi-stage modification of the Northern Slave mantle lithosphere: Evidence from zircon-and diamond-bearing eclogite xenoliths entrained in Jericho kimberlite, Canada. J. Petrol. 2006, 47, 821-858. [CrossRef]

106. Jerde, E.A.; Taylor, L.A.; Crozaz, G.; Sobolev, N.V.; Sobolev, V.N. Diamondiferous eclogites from Yakutia, Siberia: Evidence for a diversity of protoliths. Contrib. Mineral. Petrol. 1993, 114, 189-202. [CrossRef]

107. Benoit, M.; Polvé, M.; Ceuleneer, G. Trace element and isotopic characterization of mafic cumulates in a fossil mantle diapir (Oman ophiolite). Chem. Geol. 1996, 134, 199-214. [CrossRef] 
108. Kopylova, M.G.; Gurney, J.J.; Daniels, L.R. Mineral inclusions in diamonds from the River Ranch kimberlite, Zimbabwe. Contrib. Mineral. Petrol. 1997, 129, 366-384. [CrossRef]

109. Wyllie, P.J.; Huang, W.-L. Carbonation and melting reactions in the system $\mathrm{CaO}-\mathrm{MgO}-\mathrm{SiO}_{2}-\mathrm{CO}_{2}$ at mantle pressures with geophysical and petrological applications. Contrib. Mineral. Petrol. 1976, 54, 79-107. [CrossRef]

110. Schrauder, M.; Navon, O. Solid carbon dioxide in a natural diamond. Nature 1993, 365, 42. [CrossRef]

111. Frey, F.; Green, D.; Roy, S. Integrated models of basalt petrogenesis: A study of quartz tholeiites to olivine melilitites from south eastern Australia utilizing geochemical and experimental petrological data. J. Petrol. 1978, 19, 463-513. [CrossRef]

112. Mallmann, G.; O'Neill, H.S.C. The crystal/melt partitioning of $\mathrm{V}$ during mantle melting as a function of oxygen fugacity compared with some other elements (Al, P, Ca, Sc, Ti, Cr, Fe, Ga, Y, Zr and Nb). J. Petrol. 2009, 50, 1765-1794. [CrossRef]

113. Pernet-Fisher, J.F.; Howarth, G.H.; Liu, Y.; Barry, P.H.; Carmody, L.; Valley, J.W.; Bodnar, R.J.; Spetsius, Z.V.; Taylor, L.A. Komsomolskaya diamondiferous eclogites: Evidence for oceanic crustal protoliths. Contrib. Mineral. Petrol. 2014, 167, 981. [CrossRef]

114. Yaxley, G.M.; Green, D.H. Reactions between eclogite and peridotite: Mantle refertilisation by subduction of oceanic crust. Schweiz. Miner. Petrogr. Mitt 1998, 78, 243-255.

115. Kopylova, M.; Russell, J.; Cookenboo, H. Petrography and chemistry of the Jericho kimberlite (Slave craton, northern Canada). In Proceedings of the 7th International Kimberlite Conference, Cape Town, South African Republic, 13-18 April 1998; pp. 449-451.

116. Fung, A. Petrochemistry of upper mantle eclogites from the Grizzly, Leslie, Pigeon and Sable kimberlites in the Slave Province, Canada. In Proceedings of the 7th International Kimberlite Conference, Cape Town, South African Republic, 13-18 April 1998; pp. 230-232.

117. Safonov, O.G.; Butvina, V.G. Indicator reactions of K and Na activities in the upper mantle: Natural mineral assemblages, experimental data and thermodynamic modeling. Geochem. Int. 2016, 54, 858-872. [CrossRef]

118. Clarke, D. Synthesis of nickeloan djerfisherites and the origin of potassic sulphides at the Frank Smith Mine. Mantle Sample Incl. Kimberl. Other Volcan. 1979, 16, 300-308.

119. Gorbachev, N.S.; Nekrasov, I.J. Features of the formation of synthetic and natural potassium sulfides. Dokl. Akad. Nauk SSSR 1980, 251, 682-685.

120. Sharp, Z.; Helffrich, G.; Bohlen, S.R.; Essene, E.J. The stability of sodalite in the system $\mathrm{NaAlSiO}_{4}-\mathrm{NaCl}$ Geochim. Cosmochim. Acta 1989, 53, 1943-1954. [CrossRef]

121. Dawson, J.B.; Harley, S.L. Some post-equilibrium reactions in kimberlite-derived eclogites Paper A-00081. Lithos 2009, 112, 1025-1031. [CrossRef]

122. Schulze, D.J. Low-Ca garnet harzburgites from Kimberley, South Africa: Abundance and bearing on the structure and evolution of the lithosphere. J. Geophys. Res. Solid Earth 1995, 100, 12513-12526. [CrossRef]

123. Griffin, W.L.; Shee, S.R.; Ryan, C.G.; Win, T.T.; Wyatt, B.A. Harzburgite to lherzolite and back again: Metasomatic processes in ultramafic xenoliths from the Wesselton kimberlite, Kimberley, South Africa. Contrib. Mineral. Petrol. 1999, 134, 232-250. [CrossRef]

124. Griffin, W.L.; Smith, D.; Boyd, F.R.; Cousens, D.R.; Ryan, C.G.; Sie, S.H.; Suter, G.F. Trace-element zoning in garnets from sheared mantle xenoliths. Geochim. Cosmochim. Acta 1989, 53, 561-567. [CrossRef]

125. Griffin, W.L.; Smith, D.; Ryan, C.G.; O’Reilly, S.Y.; Win, T.T. Trace-element zoning in mantle minerals; metasomatism and thermal events in the upper mantle. Can. Mineral. 1996, 34, 1179-1193.

126. Jollands, M.C.; Hanger, B.J.; Yaxley, G.M.; Hermann, J.; Kilburn, M.R. Timescales between mantle metasomatism and kimberlite ascent indicated by diffusion profiles in garnet crystals from peridotite xenoliths. Earth Planet. Sci. Lett. 2018, 481, 143-153. [CrossRef]

127. Walter, M.J. Melting of garnet peridotite and the origin of komatiite and depleted lithosphere. J. Petrol. 1998, 39, 29-60. [CrossRef]

128. Workman, R.K.; Hart, S.R. Major and trace element composition of the depleted MORB mantle (DMM). Earth Planet. Sci. Lett. 2005, 231, 53-72. [CrossRef]

129. Pearson, D.; Snyder, G.; Shirey, S.; Taylor, L.; Carlson, R.; Sobolev, N. Archaean Re-Os age for Siberian eclogites and constraints on Archaean tectonics. Nature 1995, 374, 711. [CrossRef]

130. Aulbach, S.; Heaman, L.M.; Jacob, D.E.; Viljoen, K. Ages and sources of mantle eclogites: ID-TIMS and in situ MC-ICPMS Pb-Sr isotope systematics of clinopyroxene. Chem. Geol. 2019, 503, 15-28. [CrossRef] 
131. Maas, R.; Kamenetsky, M.B.; Sobolev, A.V.; Kamenetsky, V.S.; Sobolev, N.V. Sr, Nd and Pb isotope evidence for a mantle origin of alkali chlorides and carbonates in the Udachnaya kimberlite, Siberia. Geology 2005, 33, 549-552. [CrossRef]

132. Kamenetsky, M.B.; Sobolev, A.V.; Kamenetsky, V.S.; Maas, R.; Danyushevsky, L.V.; Thomas, R.; Pokhilenko, N.P.; Sobolev, N.V. Kimberlite melts rich in alkali chlorides and carbonates: A potent metasomatic agent in the mantle. Geology 2004, 32, 845-848. [CrossRef]

133. Golovin, A.; Sharygin, V.; Pokhilenko, N. Melt inclusions in olivine phenocrysts in unaltered kimberlites from the Udachnaya-East pipe, Yakutia: Some aspects of kimberlite magma evolution during late crystallization stages. Petrology 2007, 15, 168-183. [CrossRef]

134. Abersteiner, A.; Kamenetsky, V.S.; Golovin, A.V.; Kamenetsky, M.; Goemann, K. Was crustal contamination involved in the formation of the serpentine-free Udachnaya-East kimberlite? New insights into parental melts, liquidus assemblage and effects of alteration. J. Petrol. 2018, 59, 1467-1492. [CrossRef]

135. Mosenfelder, J.L.; Schertl, H.-P.; Smyth, J.R.; Liou, J.G. Factors in the preservation of coesite: The importance of fluid infiltration. Am. Mineral. 2005, 90, 779-789. [CrossRef]

(C) 2020 by the authors. Licensee MDPI, Basel, Switzerland. This article is an open access article distributed under the terms and conditions of the Creative Commons Attribution (CC BY) license (http://creativecommons.org/licenses/by/4.0/). 